\title{
Beslenme Eğitiminin Çocukların Beslenme Kararları ve Akıl Yürütme Örüntüleri Üzerindeki Etkisinin İncelenmesi*
}

\author{
Özge YILDIRIM SÜT', Ali Yiğit KUTLUCA²
}

\begin{abstract}
Öz: Bu araştırmanın amacı, beslenme eğitiminin çocukların beslenme kararlarını ve akıl yürütme örüntülerini nasıl etkilediğini keşfetmektir. Bu durum çalışması, 2020-2021 eğitim öğretim yılı Elazı̆̆ ilinde bir anaokulunda öğrenim gören 6072 aylık sekiz çocuğun katılımı ile gerçekleştirilmiştir. Araştırma kapsamında örnek menü seçenekleri, haftalık etkinlikler ve video kayıtlar aracılığıyla veriler toplanmıştır. Çocuklar, haftada iki gün olacak şekilde toplamda altı haftalık beslenme eğitimine dâhil edilmişlerdir. Eğitimin b1şında ve sonunda çocuklara sağ lıklı, sağllklı gibi görünen ve sağllksız olacak şekilde beslenme uzmanı tarafından hazırlanmış olan kahvaltı, ö̆len ve akşam yemeği menüleri sunulmuştur. Çocukların üç alternatifli menülerden birini seçmeleri istenmiştir. Eğitim öncesi ve sonrasında çocukların kararları -1, 0, 1 şeklinde puanlandırılırken akıl yürütme örüntülerini analitik rubrik aracıllğıyla değerlendirilmiştir. Sonuçlar, beslenme eğitiminin çocukların menü seçimlerini olumlu etkilediğini ve onların daha mantıksal akıl yürütmeler yapmalarını sağladığını göstermiştir. Bu sonuçlar, literatür temelli olarak derinlemesine tartışılmış ve pedagojik önerilerde bulunulmuştur.
\end{abstract}

Anahtar Sözcükler: Okul öncesi, Erken çocukluk, Beslenme eğitimi, Karar verme, Akıl yürütme, Akıl yürütme örüntüleri

\section{Investigating the Effect of Nutrition Education on Children's Nutrition Decisions and Reasoning Patterns}

\begin{abstract}
The aim of this research is to explore how nutrition education affects children's nutritional decisions and reasoning patterns. This case study was carried out with the participation of eight children aged 60-72 months studying in a kindergarten in the province of Elazig in the 2020-2021 academic year. Within the scope of the study, data were collected through sample menu options, weekly activities and video recordings. Children were included in nutrition education for a total of six weeks, two days a week. At the beginning and end of the education, children were presented with breakfast, lunch and dinner menus prepared by a nutritionist in a way that would be healthy, seemingly healthy and unhealthy. Children were asked to choose one of the three alternative menus. While the children's decisions were scored as $-1,0,1$ before and after the education, their reasoning patterns were evaluated through an analytical rubric. The results showed that nutrition education positively affects children's menu choices and enables them to make reasoning that is more rational. These results were discussed in depth based on the literature and pedagogical recommendations were made.
\end{abstract}

Keywords: Preschool, Early childhood, Nutrition education, Decision-making, Reasoning, Reasoning pattern \\ * Bu makale, birinci yazarın ‘Beslenme Eğitiminin Okul Öncesi Öğrencilerinin Beslenme Davranışları ve Karar Verme Faktörleri Üzerine Etkisinin \\ İncelenmesi' başlıklı yüksek lisans tezinden üretilmiştir. \\ 1 İstanbul Aydın Üniversitesi, Lisansüstü Eğitim Enstitüsü, Okul Öncesi Eğitimi, İstanbul, Türkiye, e-posta: o.ozgeyildirim@hotmail.com, \\ ORCID: https://orcid.org/0000-0002-9836-6750 \\ 2 İstanbul Aydın Üniversitesi, Eğitim Fakültesi, Okul Öncesi Öğretmenliği, İstanbul, Türkiye, e-posta: alikutluca@aydin.edu.tr, \\ ORCID: https://orcid.org/0000-0002-1341-3432
}


Genel olarak bütün toplumların amacı, çocuklarının her yönden sağlıklı bağımsız bireyler olmasıdır. Bunun sağlanmasında birçok faktör etkilidir. Bunlardan birisi ise beslenmedir. Bireyler dengeli ve yeterli beslendikleri zaman zihinsel, fiziksel, sosyal, duygusal açıdan gelişmiş, verimli ve sağlıklı olurlar (Obalı, 2009). Beslenmenin geçmişi insanlık tarihinin ortaya çıtığı döneme dayanır. Bireyin varoluşuyla birlikte gelişme gösteren en önemli ihtiyaçlardan birisidir (Işkın ve Sarışık, 2017). Beslenme bilgisi, bireyin, toplumun ve ailelerin beslenme alışkanlıkları üzerinde çok etkili bir role sahiptir. Dengeli ve yeterli beslenmeme ile oluşan sorunların önüne beslenme eğitimiyle geçilebilir (Kutluay-Merdol, 2012). Besin seçimleri ve beslenme bilgilerini içinde barındıran beslenme eğitimleri okullarda eğitim programlarında olması oldukça önemlidir. Okul aracılığı ile sağlıklı besinleri teşvik etmek çocukların hayatları boyunca sağlıklı beslenme alışkanlıklarını oluşturması için büyük bir adımdır (Panunzio, Antoniciello, Pisano ve Dalton, 2007). Çocukların bilişsel ve davranışsal becerilerinin gelişmesi, öğrenme kapasitelerinin artması için yeterli ve dengeli beslenmenin gerektiği konusunda bilim insanları aynı fikirdedir (Ruel ve Alderman, 2013). Fakat beslenmenin önemi yeterince anlaşılamadığı için beslenme eğitimi de yaygınlaşamamıştır. Özellikle çocuğun hayatındaki en özel dönemlerden birisi olan erken çocukluk döneminde çocuklara fırsat ve deneyim kazandırmak için yapılan eğitimlerin çocuğun bilişsel, fiziksel ve kişilik gelişimi ve sosyal davranışları üzerinde daimî bir etkisinin olduğu yadsınamaz bir gerçektir (Bredekamp, 2015; Dobbins, McCready ve Rackas, 2016). Dolayısıla beslenme eğitimini okul öncesi eğitimden itibaren başlayacak şekilde düşünmek önem arz etmektedir.

Birçok araştırmaya göre sağlıklı beslenme alışkanlığının temeli erken çocukluk döneminde atılır (örn; Dietz, 2004; Neelon ve Briley, 2011). Burada temel amaç, çocukların sağlıklı bir şekilde büyümesini ve gelişmesini ve özellikle okul performansını artmasını sağlamaktır (Gökçay ve Garipağaoğlu, 2002). Bu nedenle okul, beslenme eğitiminin niteliği ve sağlıklı beslenme alışkanlıklarının kazandırılması için en ideal yerdir (Duffy, 2012). Fakat bu dönemdeki çocukların karar verme becerileri tam olarak gelişemediği için hem ailelerine bağımlıdırlar hem de taklitçidirler (Kikafunda ve Tumwine, 2006). Örneğin, ailede yemek seçen biri varsa olumlu beslenme davranışı geliştirmede zorlanacaktır (Kutluay-Merdol, 2012). Ayrıca bu dönemde çocukların besinlere karşı tavır koymaları en belirgin özelliklerindendir. Sebze grubu en az sevdikleri besin grubudur (Savage, Peterson, Marini, Bordi ve Birch, 2013).

Erken çocukluk döneminde dengeli ve sağlıklı beslenme bilincinin oturması için, okulda verilecek beslenme programları, çocukların bedensel ve sağlıklı gelişiminde hem de okul başarısının artmasında önemli rol oynamaktadır. Bireylerin bilgi alma ve alışkanlık kazanmaya en yatkın oldukları erken çocukluk döneminde çocuklara verilecek beslenme eğitimi çocukların davranışları üzerinde daha kalıcı izli etki bırakacaktır (Wyse, Campbell, Nathan ve Wolfenden, 2011). Çocukların daha dengeli ve sağlıklı beslenmelerini sağlayacak, geleceğin yetişkinleri olacak çocuklar sağlıklı nesillerin temelini oluşturacaktır (Kasnakoğlu ve Ülgüray, 2003). Ayrıca erken çocukluk dönemindeki nitelikli beslenme eğitiminin çocukların beslenme davranışlarını, kararlarını ve akıl yürütme niteliklerini geliştireceği düşünülmektedir (Slaughter ve Ting, 2010).

Erken çocukluk dönemindeki çocukların karar verme süreçleri incelendiği zaman bilişsel gelişimin bir parçası olduğu bilinmektedir. Çocuklar yaşamla ilgili deneyimler elde ettikçe farklı problemlerle karşılaşır ve problem çözümünde karar verme becerisini kullanır. Duygular, toplumsal ve sosyal faktörler, zaman, stres, yaş, düşünce, kişilik özellikleri gibi birçok faktör karar vermeyi etkilemektedir (Pekdoğan ve Ulutaş, 2018). Dolayısıyla erken çocukluk dönemindeki çocukların karar verme süreçlerinin incelenmesi, karar verebilme becerilerinin gelişmesi açısından önemli rol oynamaktadır. Özetle bu çalışmada beslenme eğitimine dâhil olan çocukların beslenme kararları ve akıl yürütme örüntülerinin nasıl değiştiği incelenmiştir.

\section{Araştırmanın Önemi}

$\mathrm{Bu}$ araştırmanın temel doğası, beslenme konusu temelindeki kararları ve akıl yürütme örüntülerini keşfetmek üzerinedir. Bu nedenle bağlam okul öncesinde fen eğitimi süreçlerine de temas etmektedir. Çocuklar fen eğitimi ile meraklarını uyandırabilir, dünyayı, çevreyi ve kendi organizmalarını öğrenebilirler. Okul öncesi dönemde fen eğitiminin amaçları içerisinde, yaparak yaşayarak öğrenmelerine olanak sağlayacak, etrafı keşfetmelerini sağlayacak etkinliklerin sunulması vardır (Davies ve diğerleri, 2003). Sadler (2004) 
sosyobilimsel konuların çocukların bilim okuryazarı bireyler haline gelmelerini sağlamak için etkili bağlamlar sunduğunu belirtmiştir. Buna göre sosyobilimsel konuların öğrenilmesi; merak, müzakere, eleştirel düşünme ve karar verme süreçlerinin kullanılmasıyla sağlanır (Klosterman ve Sadler, 2010). Bilim, teknoloji ve toplum ilişkilerini ikilemli bir şekilde içerisinde barındıran bu konular, öğrencilere ilgi çekici ve kişisel olarak anlamlı gelmektedir (Zeidler ve Nichols, 2009). Literatürde en çok çalışılan ve en bilinen sosyobilimsel konular; GDO, iklim değişikliği, küresel ısınma, biyoteknoloji uygulamaları şeklindedir (Kutluca, 2021; Kutluca ve Aydın, 2017). Beslenme konusunun da bu konularla ilişkili olduğu düşünülebilir. Çocukların bu konular aracilığıyla karar verme ve akıl yürütme süreçlerine dâhil olmaları, onların bilim okuryazarı bireyler olmalarını sağlayacaktır (Zeidler, Herman ve Sadler, 2019).

Çocukların akıl yürütme ve karar verme becerilerinin gelişiminde, sosyobilimsel aktiviteler önemli rol oynamaktadır. Bu tür aktiviteler, çocukların sorumluluk sahibi olmaları, olaylara eleştirel bakış açısıyla bakabilmeleri ve bilinçli kararlar verebilmelerini sağlamaktadır (Lee, 2007). Osborne'a (2014) göre sosyobilimsel aktiviteler öğrencilerin tartışma becerilerini de artırmaktadır. Albe'ye (2008) göre ise sosyobilimsel konular üzerinde konuşmak çocukları motive etmek ve sınıfta bu konulara olan ilginin yoğunlaşmasına sebep olmaktadır.

Günümüzdeki en popüler sosyobilimsel konulardan biri de sağlık, başarı ve mutluluğumuzu önemli bir şekilde etkileyen kaliteli ve dengeli beslenmedir. Bu konu sağlıklı beyin ve vücutlara sahip nesillerin yetişmesi için oldukça önemlidir. Fakat ülkemizdeki eksik beslenme eğitiminden dolayı ciddi boyutta sorunlar yaşanmaktadır. Özellikle çocuklarda aşırı dengesiz ve sağlıksız beslenmeden ötürü şişmanlık ve ileriki yaşlarda karşılarına çıkacak kalp damar hastalıkları gözlemlenmektedir. Bu nedenle, toplum sağlığı için dengeli beslenmenin öneminin farkına varılmalı ve öğrenciler bu bilinç ile yetiştirilmelidir (Goloğlu, 2009). Çocuklarda kullanılan geleneksel beslenme uygulamalarının, ebeveynlerin çocukları yemeye zorlamalarının ve çocukları sınırlandırmaya çalışmalarının, lezzetli ve enerjileri yüksek gıdalara teşvik etmelerinin obezojenik bağlamda olumsuz etkileri vardır (Birch ve Doub, 2014). Meyve, sebze gibi sağlıklı yiyecekleri yeme alışkanlığını kazandırmak için erken çocukluk dönemi en uygun zamandır (Mennella, Nicklaus, Jagolin ve Yourshaw, 2008). Bu zamanlar oldukça iyi değerlendirmeli, en kritik dönemlerde çocukların alışkanlıklarının doğru şekilde oturtulması gerekmektedir. Jaime ve Lock (2009), dünyada ilk ve ortaokullarda uygulanan şişmanlığın azaltılması için uygulanan beslenme eğitimlerini inceledikleri çalışmalarda, Kasım 2007 ye kadar yayınlanmış, literatürü değerlendirmişlerdir. Tüm dünyada obezite ile mücadele için oluşturulan politikalar için önemli temel ortamın okul olduğunu belirtmiştir. Berge (2009) çalışmasında 2000 yılından sonra yayımlanan, çocuklarda ve ergenlerdeki obezite ile ebeveyn, aile alışkanlıkları ve kardeşlerle olan ilişkileri değerlendiren çalışmaları incelemiştir. Literatürde bu konuda yapılan çalışmaların çoğu, obezite ile ebeveyn ve kardeşlerle olan ilişkinin anlamlı bir ilişkide olduğunu göstermiştir (Black ve Heidkamp, 2018; Sabbağ, 2011). Bunun için yapılacak olan müdahalenin okul ortamı ve ev ortamında yapılması önerilmiştir. Dolayısıyla çocukların bu dönemde nitelikli beslenme eğitimlerine dâhil edilmesi onların kararlarını nitelikli akıl yürütme örüntüleri aracılı̆̆ıla vermelerine olanak sağlayacaktır (Hu ve diğerleri, 2010).

$\mathrm{Bu}$ rasyonel temelinde mevcut literatür derinlemesine incelenmiş ve sosyobilimsel konular, karar verme ve beslenme eğitimi üzerine ayrı ayrı çalışmalar yapıldı̆̆ı görülmüştür. Karar verme ile ilgili çalışmaların genellikle ortaöğretim öğrencileri ve öğretmen adayları ile yapıldığı belirlenmiştir (örn; Adal, 2019; Çapkınoğlu, 2015). Literatürde, okul öncesi öğrencilerinin katılımıyla yapılan çalışmalar (Pekdoğan, 2015; Koçyiğit, 2015; Demirtaş ve Sucuoğlu, 2009) olsa da sosyobilimsel konularda karar verme ile ilgili herhangi bir araştırma yapılmadığı görülmüştür. Aynı durum akıl yürütme örüntüleri bağlamı için de geçerlidir. Literatürde sosyobilimsel konu bağlamında akıl yürütme örüntülerine odaklanan fazlaca araştırma bulunmaktadır (örn; Dawson ve Venville, 2009; Sicimoğlu, 2020; Herman, Zeidler ve Newton, 2018; Öztürk ve Yılmaz-Tüzün, 2017). Fakat okul öncesi bağlamında gerçekleştirilmiş herhangi bir araştırma bulunmamaktadır. Uluslararası çalışmalar incelendiğinde karar verme ve akıl yürütme becerileriyle ilgili yapılan araştırmalarda çoğunlukla sosyobilimsel aktiviteler kullanılmış ve çocuklar tartışmaya sevk edilerek kendi düşüncelerinin ortaya çıkması, karar verme aşamasında belirli dayanaklar oluşturup oluşturmadıkları incelenmiştir (örn; Dawson ve Venville, 2020; Gao, Wei, Bai, Lin ve Li, 2009). Yapılan çalışmalar çoğunlukla ilköğretim, ortaöğretim öğrencileri ve yetişkin bireylerle, akıl yürütme ve karar verme süreçleri, karar verme 
stratejileri ve karar verme modelleri konuları üzerinedir (örn; Chen, Chen ve Ma, 2017; Murray ve diğerleri, 2018; Pratiwi, Prahani, Suryanti ve Jatmiko, 2019). Beslenme ilgili araştırmalara bakıldığında ise erken çocukluk bağlamına önem verildiği ve bu alanda birçok çalışma yapıldığı ortaya çıkmıştır (örn; Koç, 2020, Ransley ve diğerleri, 2010; Sharma, Hedberg, Skala, Chuang ve Lewis, 2015; Şen, 2020). Fakat akıl yürütme ve karar verme süreçleriyle ilişkilendirilmiş hiçbir araştırmaya rastlanmamıştır.

Özetle, yukarıda belirtilen rasyoneller ve literatürdeki boşluk temelinde bu araştırmanın amacı, beslenme eğitiminin çocukların beslenme kararlarını ve akıl yürütme örüntülerini nasıl etkilediğini keşfetmektir. Bu amaç doğrultusunda aşağıdaki araştırma problemlerine yanıt aranmıştır.

1. Beslenme eğitimi 60-72 aylık çocukların menü kararlarını nasıl etkiler?

2. Beslenme eğitimi 60-72 aylık çocukların menü kararları sırasındaki informal akıl yürütme örüntülerini nasıl etkiler?

\section{Yöntem}

Çalışma nitel araştırma yöntemlerinden biri olan durum çalışması ile yapılmıştır (Hancock ve Algozzine, 2006). Creswell ve Poth'a (2016) göre durum çalışması; araştırmacının zaman içerisinde sınırlandırılmış bir veya birkaç durumu çoklu kaynakları içeren veri toplama araçları (gözlemler, görüşmeler, görsel-işitseller, dokümanlar, raporlar) ile derinlemesine incelediği, durumların ve duruma bağlı temaların tanımlandığı nitel bir araştırma yaklaşımıdır. Bu araştırmada ele alınan durumlar, çocukların beslenme kararları ve akıl yürütme örüntüleridir. Bu nedenle araştırma, çoklu durum çalışması tasarımına sahiptir (Yin, 2011). Bu kapsamda ilk olarak tüm katılımcılara örnek besin menüleri sunulmuş ve bu menüler arasından bireysel ve tüm sınıf olarak seçim yapmaları istenmiştir. İkinci aşamada katılımcılar altı haftalık beslenme eğitimine dâhil edilmişlerdir. Son aşamada ise sürecin başında olduğu gibi bireysel ve grup olarak örnek menü seçimleri gerçekleştirilmiştir. Özellikle grup etkinliği sırasında, müzakere süreçleri işletilmiştir.

\section{Araştırmanın Geçerliliği ve Güvenilirliği}

Bilimsel bir araştırmada geçerlilik ve güvenilirlik en önemli ölçütler arasında yer almaktadır. Nicel araştırmalar ve nitel araştırmaların geçerlilik ve güvenilirlik ölçütleri farklıdır (Yıldırım ve Şimşek, 2013). Nitel araştırmada geçerlilik, araştırmacının çalışmayı tarafsız bir şekilde sonuca ulaştırmasıdır (Baltacı, 2019). Merriam, (2013) nitel araştırmalarda geçerlilik ve güvenilirliğin sağlanması için inandırıcılığın en üst seviyede olması gerektiğini savunmuştur. Guba ve Lincoln (1982) inandırıcılık için kriterleri dört ana başlıkta toplamıştır. Bu kriterler; inanılırlık, güvenilebilirlik, onaylanabilirlik ve aktarılabilirlik şeklindedir (Başkale, 2016). İnanılırlık iç geçerlilik kavramına denk gelmektedir. İnanılırlığı artırmanın en etkili yöntemlerinden biri çalışmamanın uzun süreli etkileşim içerisinde yapılmasıdır. Araştırmacının çalışma ortamında bulunması hem uzun süreli etkileşimi sağlayacak hem de katılımcılara karşı önyargıda bulunmasını engelleyecektir. Araştırmacının doğru bilgiler almasını sağlayacaktır (Houser, 2015). Bu çalışmada ise uygulamanın daha önce derse girilen bir sınıfta yapılması, uygulamanın altı hafta sürmesi ve tüm katılımcıları önceden tanınıor olunması inandırıcılığı artırıcı bir faktördür. İnanılırlığı artırmanın bir diğer yöntemi de uzman görüşleridir. Alanında uzman kişiler tarafından araştırmanın çeşitli boyutlarıyla incelenmesi istenir (Creswell, 2003). Bu çalışmada da alanında uzman kişilerden görüşeler alınarak araştırma işleyişinde değişikler, düzenlemeler yapılmıştır. Güvenilebilirliği sağlamak için tüm uygulamalar çapraz kontrol aracillğıyla gerçekleştirilmiş ve bulgularda doğrudan alıntılara yer verilmiştir. Onaylanabilirlik objekiflik kavramına denk gelmektedir. Buradaki amaç toplanan verilerin mümkün olduğunca kaydedilmesini gerektirir. Aynı zamanda çalısmanın onaylanabilir olması verilerin eksiksiz ve yanlışsız yazılmasını gerektirir (Houser, 2015). Bu çalışmada da tüm uygulamalar videoya kaydedilmiş ve eksiksiz ve yanlışsız bir şekilde araştırmaya yansıtılmıştır. Aktarılabilirlik, dış geçerlilik kavramına denk gelmektedir. Çalışmanın aktarılabilir olması için verileri net ve doğru bir şekilde sunabilmek gerekir. Bu çalışmada da aktarılabilirliği sağlamak için tüm ayrıntılar detaylı bir şekilde sunulmuştur. 


\section{Çalışma Grubu}

Araştırmaya 2019-2020 eğitim öğretim yılında Elazığ ilinde özel bir anaokulunda hazırlık sınıfında öğrenim gören 60-72 aylık sekiz çocuk katılmıştır. Çocukların özellikleri aşağıda detaylıca incelenmiştir. Katılımcıların gerçek isimleri yerine takma isimler kullanılmıştır. Katılımcıların hepsi 2015 doğumludur. En büyük katılımcı ile en küçük katılımcının aralarındaki ay farkı dokuzdur. Sekiz katılımcı da aynı sınıfta öğrenim görmektedir.

K-1, sınıfın en popüler öğrencisidir. Fiziksel olarak arkadaşlarına oranla boyu uzundur. İletişim konusunda kendini çok iyi ifade edebilmektedir. Jest ve mimiklerini oldukça uygun kullanmakta ve derse aktif katılım sağlamaktadır. Çok aşırı olmasa da bazı yemeklerde seçici davranabiliyor. K-2, Yaşıtlarına oranla oldukça kararlı ve inatçı bir yapısı vardır. Konuşmak için çok fazla söz hakkı almaz. Ancak kendisine söz hakkı verildiği zaman oldukça mantıklı şekilde kendini ifade eder. Yemek konusunda oldukça seçici ve inatçıdır. Her yemek konusu açıldığında ben sadece patates yiyerek mutlu oluyorum diyerek belirtir. K-3, genelde kız arkadaşlarıyla oyun oynamaktan hoşlanır. Kırılgan bir yapıya sahiptir. Çabuk küsme huyu vardır. Konuşmak istediği an söz hakkı kendine verilmezse hemen küsebilir. Sonrasında derse katılmayı reddeder. Yemek yeme konusunda aşırı seçiciliği yoktur.

K-4, aşırı hassas ve oldukça sıcakkanlı biridir. Ancak aşırı sabırsız ve çok çabuk ağlayabilen bir özelliği vardır. Hırsı kendine zarar verebilecek boyuttadır. Her oyunu, her yarışmayı kazanmak ister, kazanamayınca hemen ağlamaya başlar. Konuşmak istediği an söz hakkı alamazsa da hemen ağlamaya başlar. K-5, arkadaşlarıyla iletişimi oldukça iyi oyun oynamayı, ders çalışmayı ve okula gelmeyi çok seven bir yapısı vardır. Yemek yemeyi çok sever ve asla yemek seçmez. K-6 bilişsel anlamda yaşıtlarından beklenen düzeyde özellikler gösterse de sınıf arkadaşlarına göre bilişsel anlamda daha başarılıdır. İlk girdiği ortamlarda çok çekingen davranır. Yeni tanıştığı insanların yanında oldukça tedirgindir. Beslenme konusunda çok aşırı seçici değildir.

K-7, üç yıldır aynı okula gelmektedir. Tanıdığı ortamlarda rahat bir yapıya sahip olsa da bire bir kalındığında veya tanımadığı ortamlarda oldukça sessizleşir. Artikülasyon bozukluğu olmasından kaynaklı bazen sessizleşir. K-8, fiziksel olarak da doğum yılı olarak da sınıfın en küçük öğrencisidir. Kararlı ve inatçı bir yapısı vardır. Beslenme konusunda seçici bir yapısı vardır. Genel olarak sadece sevdiği yemekleri yeme eğilimindedir.

\section{Veri Kaynakları}

$\mathrm{Bu}$ araştırmadaki ana veri kaynağı örnek menü seçenekleridir. Örnek menüler beslenme uzmanı ile birlikte hazırlanmıştır. Sonrasında iç geçerliliği artırmak adına başka bir uzman beslenme uzmanından görüş alınmıştır. Sonucunda menüler üç ayrı öğün kahvaltı, öğlen yemeği, akşam yemeği ve üç ayrı şekilde sağllkll, sağlıksız sağllklı görünümlü sağllksız olarak son halini almıştır (Tablo 1).

Tablo 1. Örnek Menü Seçenekleri

\begin{tabular}{|c|c|c|c|}
\hline Durumu & Kahvaltı & Öğlen Yemeği & Akşam Yemeği \\
\hline Sağlıklı & $\begin{array}{l}\text { Haşlanmış yumurta, Bal, Zeytin, } \\
\text { Söğüş sebze, Süt }\end{array}$ & $\begin{array}{l}\text { Etli türlü, Şehriyeli pirinç } \\
\text { pilavı, Ayran }\end{array}$ & $\begin{array}{l}\text { Etli kuru fasulye, Bulgur } \\
\text { pilavı, Cacık }\end{array}$ \\
\hline Sağlıksız & $\begin{array}{l}\text { Hellim peynir, Yumurtalı ekmek, } \\
\text { Patates kızartması, Zeytin, } \\
\text { Meyve suyu }\end{array}$ & $\begin{array}{l}\text { Kizartılmış tavuk köfte, } \\
\text { Soslu makarna, Kola }\end{array}$ & $\begin{array}{l}\text { Köfte kızartma, Patates } \\
\text { kızartma, Kola }\end{array}$ \\
\hline $\begin{array}{l}\text { Sağlıklı } \\
\text { görünen }\end{array}$ & $\begin{array}{l}\text { Beyaz peynir, Sucuk, Börek, } \\
\text { Zeytin, Meyve suyu }\end{array}$ & $\begin{array}{l}\text { Kırmızı mercimek çorba, } \\
\text { Zeytinyağlı dolma, } \\
\text { Meyvesuyu }\end{array}$ & $\begin{array}{l}\text { Sebze çorba, Karnabahar } \\
\text { haşlama, Soslu makarna }\end{array}$ \\
\hline
\end{tabular}

Tablo 1'de verilen örnek menü seçenekleri, çocuklara uygun görseller yardımıyla sunulmuştur. Örneğin sağlıklı kahvaltı menüsünde yer alan haşlanmış yumurta, bal, zeytin, söğüşs sebze ve süt besinlerinin gerçek resimleri akıllı tahta yardımıyla yansıtılarak çocukların bu besinleri görmeleri sağlanmıştır. Çocukların beslenme eğitimi öncesi ve sonrasında bu görseller yardımıyla kararlarını vermeleri sağlanmıştır. Nitel 
araştırmalarda veri toplama araçlarının çeşitli olması oldukça geçerlik ve güvenirlik ölçütlerinin başında gelmektedir (Flick, 2018). Bunun için alan ve gözlem notları kullanılmıştır. Uygulama-veri toplama sürecinin başından sonuna kadar video kayıtlarından yararlanılmıştır. Araştırmacılar daha önceden uygulamanın yapılacağı sınıfta oturma düzenini ve kamera konumlandırmasını yapmak için gitmiştir. İç geçerliliği ve dış denetimi sağlamak adına, katılımcı olamayan ancak aynı okulda aynı yaş grubunda farklı bir sınıfta eğitim gören çocuklarla pilot bir uygulama yapılmıştır. Pilot uygulamadan sonraki hafta asıl uygulama başlamıştır. Yapılan her etkinlik video kayıt altına alınmıştır. Kamera her seferinde sabit konumda çekim yapmıştır. Çekimler uygulamadan uygulamaya fark etmek üzere her uygulama 30 dakika ile 60 dakika arası sürmüştür. Yapılan tüm çekimler bilgisayar ortamına aktarılmıştır. Çekimlerde ses ve görüntü oldukça nettir.

\section{Haftalık Etkinlikler (Beslenme Eğitimi)}

Beslenme eğitimi, haftada iki gün olmak üzere altı haftada 12 etkinlik yardımıyla gerçekleştirilmiştir. Her bir etkinlik, araştırmacılar tarafından geliştirilmiş ve iç geçerliliği artırmak için okul öncesi eğitiminde, fen bilimleri eğitiminde, eğitim bilimleri ve beslenme alanında uzman kişilerin de görüşleri alınarak düzeltmeler yapılmıştır. Hazırlanan etkinliklerde beslenme eğitimi ve karar verme faktörlerini izlemek ön planda olsa da erken çocukluk dönemindeki çocukların bilişsel, psikomotor, yaratıcılık, sosyal duygusal, dil ve müzik becerilerini de geliştirmeyi hedeflenmiştir. Tablo 2' de beslenme eğitimi etkinliklerinin de yer aldığı uygulamaveri toplama sürecinin aşamaları sunulmuştur.

Tablo 2. Uygulama-Veri Toplama Süreci

\begin{tabular}{|c|c|c|}
\hline Etkinliğin Adı & Etkinliğin Türü & Açıklama \\
\hline $\begin{array}{l}\text { Menü Seçiyorum } \\
\text { (Ön-test) }\end{array}$ & Fen, Türkçe Dil Etkinliği & $\begin{array}{l}\text { Hem bireysel hem de grupla menü seçimleri } \\
\text { sağlanır. }\end{array}$ \\
\hline Besinleri Taniyorum & Oyun-Türkçe Dil Etkinliği & $\begin{array}{l}\text { Besinler hakkında ön bilgilerin dışarı çıkması ve } \\
\text { yeni bilgiler edinilmesi sağlanır. }\end{array}$ \\
\hline Kola-Yumurta-Süt Deneyi & Müzik- Fen - Deney Etkinliği & $\begin{array}{l}\text { Asit ve kalsiyum kavramları üzerinde durulur. } \\
\text { Müzik ile pekiştirilir. }\end{array}$ \\
\hline Bilgin ile Besin Grupları & Fen-Türkçe Dil Etkinliği & Süt ve süt ürünleri hakkında bilgi alışverişi yapılır. \\
\hline $\begin{array}{c}\text { Şifa Verdiği Organa Benzeyen } \\
\text { Yiyecekler }\end{array}$ & Oyun- Fen-Türkçe Dil Etkinliği & $\begin{array}{l}\text { Hangi organımız için hangi besin faydalıdır } \\
\text { hakkında video izleme ardından oyun etkinliği } \\
\text { yapılır. }\end{array}$ \\
\hline $\begin{array}{l}\text { Meyveler-Sebzeler (Meyve } \\
\text { Salatası) }\end{array}$ & Fen-Türkçe Dil Etkinliği & $\begin{array}{l}\text { Meyveler ve sebzeler hakkında bilgi alışverişinin } \\
\text { ardından meyve salatası yapılır. }\end{array}$ \\
\hline Anlat Bakalım & Fen-Türkçe Dil- Oyun-Müzik Etkinliği & $\begin{array}{l}\text { Meyve sebzelerin özellikleri ve faydaları oyun yolu } \\
\text { ile pekiştirilir. }\end{array}$ \\
\hline $\begin{array}{c}\text { Bilgin ile Et, Yumurta Kuru } \\
\text { Baklagiller }\end{array}$ & Fen-Türkçe Dil- Müzik Etkinliği & Konu hakkında bilgi alışverişi yapılır. \\
\hline $\begin{array}{l}\text { Besin Tombalası- Tahıl ve } \\
\text { Türevleri }\end{array}$ & Fen-Türkçe Dil- Müzik Etkinliği & $\begin{array}{l}\text { Tahıl ve türevleri hakkında bilgi alışverişinden } \\
\text { sonra öğrenilen besin gruplarını pekiştirmek için } \\
\text { besin tombalası oyunu oynanır. }\end{array}$ \\
\hline $\begin{array}{c}\text { Günde Kaç Öğün } \\
\text { Beslenmeliyim/Hangi } \\
\text { besinlerden kaçınmalıyım }\end{array}$ & $\begin{array}{c}\text { Fen-Türkçe Dil- Okuma Yazmaya } \\
\text { Hazırlık Etkinliği }\end{array}$ & $\begin{array}{l}\text { Günlük beslenme düzeni ve zararlı besinler } \\
\text { hakkında etkinlikler yapılır. }\end{array}$ \\
\hline $\begin{array}{l}\text { Kendi Tabağımı Kendim } \\
\text { Hazırlarım }\end{array}$ & Sanat Etkinliği & $\begin{array}{l}\text { Her çocuğun kendi tercihi ile kendi besin tabağını } \\
\text { oluşturması sağlanır. }\end{array}$ \\
\hline Duyularla Tanıyorum & Fen- Oyun Etkinliği & $\begin{array}{l}\text { Gözlerimiz kapalı duyu organlarımızı kullanılarak } \\
\text { besinlerin tanınması sağlanır. }\end{array}$ \\
\hline $\begin{array}{l}\text { Son Tercih } \\
\text { (Son-test) }\end{array}$ & Fen, Türkçe Dil Etkinliği & $\begin{array}{l}\text { Etkinliklerin bitiminde çocukların menü seçimi } \\
\text { yapması sağlanır. }\end{array}$ \\
\hline
\end{tabular}


Tablo 2'de verilenlere göre ilk ve son haftalarda çocukların örnek menü seçimlerini yapmaları sağlanmıştır. Bu şekilde tüm veriler toplanmıştır. Tüm bu etkinlikler video kayıt altına alınarak tüm veriler toplanmıştır. Öncelikle hiçbir etkinlik yapılmadan her çocuğun bireysel olarak seçim yapması istenmiştir. Çocukların neden bu menüyü seçtikleri sorulmuştur. Daha sonra katılımcılara yine hiçbir uygulama yapılmadan sınıf ortamında menüler gösterilip tekrar gerekçelendirilerek seçim yapmaları istenmiştir. Sınıf ortamında seçimleri hakkında müzakere yapmalarına izin verilmiştir. Söylenen her cümle veri olarak kaydedilmiştir. Altı hafta, on iki beslenme eğitimi etkinliğinden sonra tekrar örnek menü seçimleri katılımcılara sunulup, seçim yapmaları yaptıkları seçimi gerekçelendirmeleri istenmiştir. Söylenen her cümle veri olarak kaydedilmiştir. Menü seçimleri ilk olarak bireysel ardından grup olarak gerçekleştirilmiştir. Özellikle grup etkinliği sırasında kararların müzakere edilmesi sağlanmıştır. Uygulayıcl; Neden? Nasıl? Gerekçen Nedir? Arkadaşın neden farklı söyledi? Şeklindeki sorularla etkinlik sürecini yönetmiştir.

\section{Veri Analizi}

Çalışmada her alt problem için farklı analiz yöntemleri kullanılmıştır. Bu analiz süreçleri aşama aşama açıklanmıştır. İlk olarak video kayıtları halinde toplanan veriler, yazılı hale getirilmiştir. Veriler olduğu gibi metne dönüştürülürken, video izlendiği zaman sözel olamayan davranışlara da dikkat edilmiştir. İlk alt problemin analizinde temel amaç, grubun beslenme menüleri temelindeki temel kararlarının karakterini belirlemektir. Bunun için her bir katılımcının menülere verdiği yanıtlar elde edilmiştir. Sağlıklı menü seçenlere 1 puan, sağlıklı görünen ama sağlıksız olan menüyü seçenlere 0 puan, sağlıksız olan menüyü seçenlere isen -1 puan verilmiştir (Miles ve Huberman, 2016). Burada temel gerekçe çocukların hangi tarafa daha yatkın olduğunu belirlemektir. Çocuğun puanı negatifse sağlıksız beslenme eğilimine, pozitif ise daha sağlıklı beslenme eğilimine sahiptir. Bu değerlendirme, beslenme eğitiminin çocukların beslenme tercihlerini nasıl etkilediğini görmek için hem beslenme eğitimi öncesinde hem de sonrasında yapılmıştır.

Araştırmada ikinci alt problemi yanıtlamak için ise çocukların menü kararlarını genişlettikleri yazılı veriler üzerinde Sadler ve Zeidler (2005) tarafından hazırlanan informal akıl yürütme rubriği kullanılmıştır. Rubrik ve özellikleri Tablo 3'te gösterilmiştir.

Tablo 3. Informal Akıl Yürütme Rubriği

\begin{tabular}{cc}
\hline İnformal Akıl Yürütme Örüntüleri & Özellikleri \\
\hline Akılcı (Mantıksal) & Öğrenci kendi iddiasını ortaya koyar ve gerekçelendirir. \\
Duygusal & Öğrenci verilen duruma yaklaşırken duygularını paylaşır. \\
Sezgisel & Öğrenci hiçbir sebep dile getirmeden aniden düşüncesini dile getirir. \\
\hline
\end{tabular}

Tablo 3'te de görülebileceği üzere mantıksal akıl yürütmede veriler, bilimsel kurallar, kişisel düşünceler çerçevesinde olmaktadır. Ancak bilimsel bilgiyi kullanmak zorunlu değildir. Mantıksal akıl yürütme, katılımcıların görüş ve argüman kullanımlarını temsil eder (Sadler ve Zeidler, 2005; Yang ve Anderson, 2003). Bu durum bir örnekle daha net anlatılmıştır.

K-5: İçinde sebzeler var etler var bu çok sağlıklı bir yemek olmuş. Zaten hem et hep sebze yememiz gerekir. İşte bu yüzden bu menüyü seçiyorum çok sağlıklı.

Bu örnekte de görüldüğü gibi öğrenci daha önce edindiği bilgileri kullanarak yaptığı seçimin sebeplerini söylemiştir. Görüşlerini dile getiren öğrenci yaptığı seçimin sonucunu gerekçelendirmiştir. Sağlıklı olduğu için bu seçimi yaptığını söyleyen öğrenci doğrudan mantıksal akıl yürütme yoluna gitmiştir. Duygusal akıl yürütmede ise duygular öne plandadır. Sonuçları dikkate alırlar ancak, empati ve sempati yoluna giderler. Başka fikirlerden etkilenebilirler. Ne hissettikleri ve sonuçların nasıl duygusal tatmin veya duygusal tatminsizlik oluşturacağını düşünürler (Özden, 2019). Çalışmadan bir örnekle açılanacak olursa;

K-1:Bu portakal suyu herhâlde, çok severim. Ooo sucuk var bayılırım. Yok diğer hiçbirini sevmem.

Katılımcı burada direk duyguları ile hareket etmiştir. Yediği zaman ona ne hissettireceğini düşünerek karar vermiştir. Karar vermede etkili olan tek faktör seçenekleri sevip sevmemesidir. Sevdiği besini tüketen 
çocuk sonucundan duygusal tatmine ulaşacak, sevdiği bir tadı alacaktır. Bu sebeple duygusal akıl yürütme örüntüsünü kullanmıştır. Sezgisel akıl yürütme ise aniden, akla gelen fikirlerin söylenmesi ile oluşur. En yaygın kullanılan akıl yürütme örüntüsüdür. Ne duygular göz önünde bulundurulur ne de mantık. Sonucun ne olacağı düşülmez. O an içten gelen sebepsiz yere söylenen kararlardır. Örnek verilecek olursa;

K-5: 3. menüyü seçerim. İşte

Katılımcı burada görür görmez menü seçimini yapmıştır. Sebebi sorulduğunda ise mantıksal veya duygusal hiçbir açıklama yapamamış, "işte" cevabını vermiştir. Mantıksal ve duygusal gerekçelendirme yapmayıp birden tercih yapılması sezgiler ile hareket edildiğinin bir göstergesidir. Öğrenciler mantıksalduygusal, mantıksal-sezgisel, duygusal-sezgisel, mantıksal-duygusal-sezgisel akıl yürütmeleri aynı anda yapabilirler. Örneğin, öğrenci duygusal olarak olumlu yaklaştığı bir duruma, mantıksal olarak olumsuz bakabilir (Sadler, 2004).

K-1: Yalvarırım sucuk sağlıksız bir şey olmasın. Aslında ben Hümeya 'ya karşı geleceğim ama sağlıksız olduğunu düşünüyorum ama canım çekiyor çok seviyorum o yüzden karşı gelemeyeceğim.

Burada öğrenci mantıksal-duygusal akıl yürütme örüntüsü kullanmıştır. Çünkü sucuğun sağlıksız olduğunu düşünerek, mantığı ile karar verirse arkadaşına karşı geleceğini ve ona sucuğun sağlıksız olduğu için onu seçmemeleri gerektiğini söyleyeceğini belirtmiştir. Ancak canının sucuk çektiğini ve sucuğu çok sevdiğini söyleyerek duyguları ile karar verdiği söylenebilir.

\section{Bulgular}

Araştırmanın bu kısmında verilerin analizinden elde edilen bulgular yer almaktadır. Bu bulgular her alt problem için ayrı ayrı ele alınmıştır. Bu süreçte ilk olarak beslenme eğitiminin çocukların menü kararlarını nasıl etkilediğini belirlemek için beslenme eğitimi öncesinde ve sonrasında çocukların seçtikleri menüler belirlenerek değerlendirme yapılmıştır. Son olarak beslenme eğitiminin çocukların menü kararları sırasındaki informal akıl yürütme örüntülerini nasıl değiştirdiğini belirlemek için Sadler ve Zeidler (2005) tarafından hazırlanan analitik rubrik kullanılmıştır.

\section{Çocukların Beslenme Kararlarının Değerlendirilmesi}

Araştırmanın ilk problemi, beslenme eğitiminin çocukların beslenme kararlarını nasıl değiştirdiğini ortaya çıarmaktır. Bu nedenle öğrencilerin beslenme eğitiminden önce bireysel ve grupla yaptıkları tercihler ve beslenme eğitiminden sonra yaptıkları tercihler belirlenmiş ve puanlar üzerinden değerlendirmeler yapilmıştır.

Tablo 4. Ĕ̆itim Öncesi Bireysel Beslenme Kararları

\begin{tabular}{ccccc}
\hline Katılımcı & Sabah & Öğle & Akşam & Toplam \\
\hline K-1 & 1 & 1 & -1 & 1 \\
K-2 & -1 & -1 & -1 & -3 \\
K-5 & -1 & 0 & 0 & -1 \\
K-4 & -1 & 0 & -1 & -2 \\
K-7 & -1 & 0 & 0 & -1 \\
K-6 & 0 & 0 & -1 & -1 \\
K-3 & -1 & -1 & 0 & -2 \\
K-8 & -1 & 1 & -1 & -1 \\
Toplam & -5 & 0 & -5 & -10 \\
\hline
\end{tabular}


İlk olarak beslenme eğitimi verilmeden çocuklar ile bireysel görüşmeler yapılmıştır. Bu görüşmeler neticesinde çocukların her bir öğün için bir menü seçmeleri istenmiştir. Seçtikleri menüler puanlamıştır. Her öğrenci için puanlama, Tablo 4'te verilmiştir. Buna göre katılımcılardan sadece bir tanesi kahvaltı ögününde sağlıklı menüyü seçerken altı tanesi sağlıksız olan menüyü seçmiştir. Bir tanesi ise sağlıklı gibi görünen sağlıksız menüyü tercih etmiştir. Öğlen yemeğinde ise dört katılımcı sağlıklı gibi görünen sağlıksız menüyü seçerken, katılımcılardan iki tanesi sağlıklı, diğer iki tanesi ise sağlıksız olan menüyü seçmiştir. Son olarak akşam yemeğinde ise, beş katılımcı sağlıksız olan menüyü seçerken üç katılımcı ise sağlıklı gibi görünen ancak sağlıksız olan menüyü seçmiştir. Akşam yemeğinde hiçbir katılımcının sağlıklı olan menüyü seçmediği belirlenmiştir. Beslenme eğitimi öncesinde yapılan seçimlerde, çocukların genel olarak sağlıksız besleneme eğiliminde oldukları görülmüştür.

İkinci aşamada ise yine beslenme eğitimi verilmeden ayn katılımcılara bu sefer sınıf içerisinde grup halinde aynı menüler sunularak seçim yapmaları istenmiştir. Bu seçimlerin sonuçları Tablo 5 'te verilmiştir. Ancak iki katılımcı bu etkinliğin yapıldığ gün okula gelmemiştir. Bu sebeple gelemeyen katılımcıların puanları hesaplanmayıp puan yerine * işareti ile tabloda belirtilmiştir.

Tablo 5. Eğitim Öncesi Grupla Beslenme Kararları

\begin{tabular}{|c|c|c|c|c|}
\hline Katılımcı & Sabah & Öğle & Akşam & Toplam \\
\hline $\mathrm{K}-1$ & 1 & 0 & 1 & 2 \\
\hline $\mathrm{K}-2$ & 0 & -1 & -1 & -2 \\
\hline $\mathrm{K}-5$ & 1 & -1 & -1 & -1 \\
\hline $\mathrm{K}-4$ & * & * & * & 0 \\
\hline $\mathrm{K}-7$ & -1 & 1 & 1 & 1 \\
\hline Ece & 0 & 0 & -1 & -1 \\
\hline $\mathrm{K}-3$ & 0 & -1 & 1 & 0 \\
\hline $\mathrm{K}-8$ & * & * & * & 0 \\
\hline Toplam & 1 & -2 & 0 & -1 \\
\hline
\end{tabular}

Tablo 5 incelendiği zaman sabah kahvaltısında iki kişi sağlıklı menüyü, üç kişi sağlıklı gibi görünen, kalan bir kişi ise sağlıksız olan menüyü seçmiştir. Öğlen yemeği incelendiğinde, bir kişi sağlıklı, iki kişi sağlıklı gibi görünen, üç kişi ise sağlıksız olan menüyü seçmiştir. Son olarak akşam yemeği incelendiğinde, üç kişi sağlıklı menüyü seçerken, üç kişi de sağlıksız olan menüyü seçmiştir. Bu tablo genel olarak incelendiği zaman henüz beslenme eğitimi verilmediği göze alındığında ve menülerde herhangi bir değişiklik yapılmadığı halde öğrencilerin kararlarının değiştiği görülmüştür. Bu değişim olumlu yönde seyretmiştir. Yine sağlıksız beslenme eğilimli bir sonuç çıksa dahi genel puan $-5^{\prime}$ den $-1^{\prime}$ e yükselmiştir. Bunu sebebi öğrencilerin birbirlerinin fikirlerinden etkilenmeleri olabilir. Buna örnek olarak katılımcılardan sağlanan doğrudan alıntı aşağıda yer almaktadır.

K-7: Hayır ben bu fikre karşıyım. Ben de ilk menüyü seçmiştim ama bence çorba olan menü daha sağlıklı.

K-6: Aslında K-1 doğru söylüyor. Patates kızartması sağlıklı değil.

K-7 kendi kararını söyledikten sonra "ben bu menüyü seçmiştim ama" diyerek arkadaşının fikrinden etkilendiğini göstermiştir. Aynı şekilde K-6 ise önce patates kızartmasını seçtiği halde sonra K-1'in kararını olumlu bularak kendi kararını değiştirmiştir.

Beslenme eğitimi öncesi tüm veriler alındıktan sonra toplam altı haftalık bir beslenme eğitimi verilmiştir. Bu eğitimin öncelikli hedefi çocukların eğlenerek öğrenmesidir. Verilen eğitim sonucunda tekrar menüler çocuklara gösterilerek seçim yapmaları sağlanmıştır. Yaptıkları seçimlerin sonuçları Tablo 6'da yer almaktadır. 
Tablo 6. Eğitim Sonrası Beslenme Kararları

\begin{tabular}{ccccc}
\hline Katılımcı & Sabah & Öğle & Akşam & Toplam \\
\hline K-1 & 1 & 1 & 1 & 3 \\
K-2 & 1 & 0 & 0 & 2 \\
K-5 & 1 & 1 & 0 & 3 \\
K-4 & 1 & 1 & 1 & 3 \\
K-7 & 1 & 1 & 1 & 1 \\
Ece & 0 & 0 & 1 & 3 \\
K-3 & 1 & 1 & 0 & 1 \\
K-8 & 1 & 0 & 5 & $\mathbf{1 7}$
\end{tabular}

Beslenme eğitimi sonrasında sabah, öğlen, akşam olmak üzere hiçbir öğrencinin sağlıksız bir menü seçmediği görülmüştür. Kahvaltıda bir öğrenci dışında tüm öğrenciler sağlıklı olan menüyü seçmiştir. Bireysel ve grup olarak yapılan seçimler değişmediği için bulgular tek bir tablo yardımıyla yorumlanmıştır. Sağlıklı olan menüyü seçmeyen öğrenci ise sağlıklı gibi görünen sağlıksız olan menüyü seçmiştir. Öğlen yemeğinde üç öğrenci sağlıklı gibi görünen sağlıksız menüyü seçerken kalan öğrenciler sağlıklı olan menüyü tercih etmiştir. Akşam yemeğinde ise yine üç öğrenci sağlıklı gibi görünen sağliksız menüyü seçerken diğer öğrenciler sağlıklı olan menüyü seçmiştir. Beslenme eğitimi öncesinde yapılan bireysel seçimler, sınıf ortamında yapılan grup ile seçimler ve beslenme eğitimi sonrasındaki seçimlerini sonuçları Şekil I'de sunulmuştur. Puan pozitife doğru çıktıkça çocukların sağlıklı beslenme eğiliminde oldukları, negatif yönünde gittikçe sağlıksız beslenme eğiliminde oldukları söylenebilir.

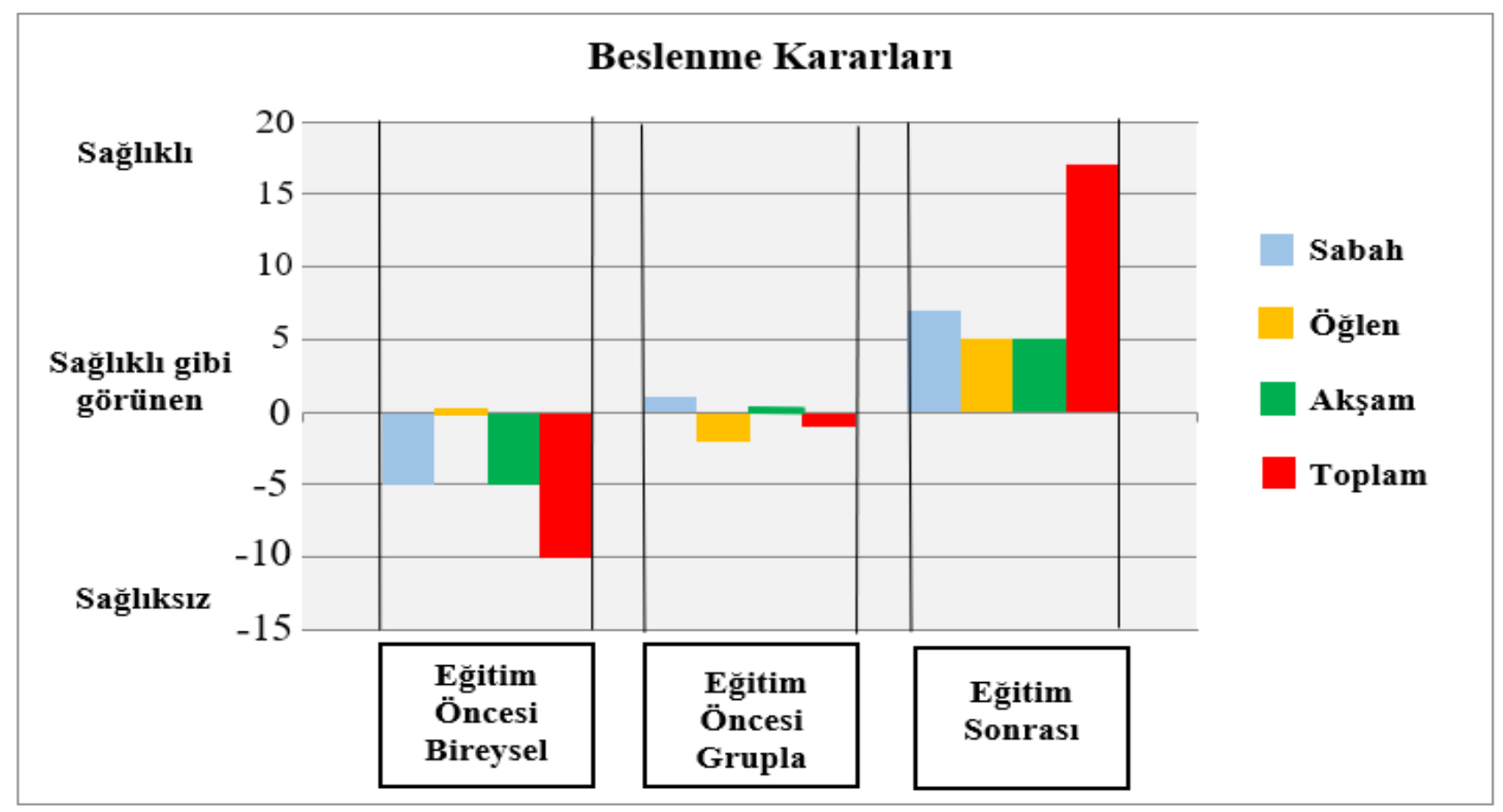

Şekil 1. Beslenme Kararları

Şekil 1'de verilen bulgulara göre beslenme eğitiminin çocukların beslenme bilgi düzeylerine ve sağliklı beslenme eğiliminde olmalarına katkı sağladığı aşikârdır. Pandemi sebebi ile bazı öğrencilerin eğitimlerin 
hepsine katılamamalarına rağmen sonuçlarda kayda değer bir fark belirlenmiştir. Bunun göstergesi olarak aşağıda öğrencilerin doğrudan alıntılarına yer verilmiştir.

K-1: Ben de sucuğu çok seviyorum ama yine de seçim yaptığımızda sağlıklı olan menüyü seçeceğim.

K-5: Ben artık annem sucuk yaptığında sofradan kalkıyorum çünkü hiç sağlıklı değil.

K-3: Benim en sevdiğim burada bal. Hem bal enerji verir bize. Enerjiye çok ihtiyacımız var.

K-7: Ben de hep patates istiyordum ama şimdi yumurta yiyeceğim. Hem Bilgin vardı ya o ne diyordu. Ben bunu hatırlıyorum. Yumurta yemek istiyorum.

K-4: Bir kere söylemiştik ya süt içeceğiz iki kere günde. Ben kahvaltıda içeceğim. Hem okulda da içmedik mi. Ben süt olan menüyü istiyorum. Hem yumurtada var.

K-6: Ben yılbaşında minnacık kola içtim ama çok az diye karnım ağrımadı dişerim kötü olmadı.

K-8: Asit vardı. Kolada deney de yapmıştık çok zararlı.

Katılımcların cümleleri incelendiği zaman beslenme eğitiminin çocuklar üzerinde bıraktığı etki çok net anlaşılmaktadır. Katılımcların kendinden emin duruşlarıyla öğrendiklerini özgüvenli ve doğru olduğundan emin bir şekilde ifade ettikleri görülmüştür. Ayrıca besinlerin hangi besin grubuna ait oldukları, günde ne kadar tüketmeleri gerektiği gibi konuları özümsedikleri ve seçimlerini bu yönde yaptıkları gözlemlenmiştir. Katılımcılar kendilerini ifade ederken oldukça rahat bir tavır sergilemenin yanında aldıkları beslenme eğitiminden hatırladıklarını da net bir şekilde belirtmişledir. Beslenme eğitimi süresince öğrendikleri bilgileri bunu derste öğrenmiştik diye belirtmişleridir. Katılımcılar sınıf içerisinde konuşurken hem ev hayatlarından hem de okul hayatlarından örnekler vermişleridir. Öğrendikleri bilgileri günlük hayatlarına uyguladıklarını da belirtmişlerdir. Beslenme eğitiminden önce daha çok sağlıksız beslenme eğiliminde olan öğrenciler beslenme eğitimi sonrasında sağlıklı beslenme eğiliminde oldukları ve bunu gerekçelendikleri görülmüştür.

\section{Akıl Yürütme Örüntülerinin Değerlendirilmesi}

Çalışmanın bu aşamasında katılımcıların beslenme eğitiminden önce ve beslenme eğitiminden sonraki karar verme süreçleri incelenmiştir. Karar verirken kullandıkları akıl yürütme örüntüleri belirlenmiştir. Beslenme eğitimi verilmeden önce, öğrencilerin verdikleri cevaplar doğrultusunda belirlenen örüntüler Tablo 7'de gösterilmiştir.

Tablo 7. Eğitim Öncesi Akıl Yürütme Örüntüleri

\begin{tabular}{cccc}
\hline Katılımcı & Kahvaltı & Öğlen & Akşam \\
\hline K-1 & Duygusal & Duygusal & Duygusal \\
K-2 & Duygusal & Duygusal & Duygusal \\
K-5 & Sezgisel & Duygusal & Duygusal \\
K-4 & Duygusal & Duygusal & Duygusal \\
K-7 & Sezgisel & Mantıksal & Sezgisel \\
K-6 & Sezgisel & Duygusal & Duygusal \\
K-3 & Duygusal & Sezgisel & Duygusal \\
K-8 & Duygusal & Duygusal & Duygusal
\end{tabular}

Tablo 7'de görüldüğü gibi beslenme eğitimi öncesinde öğrenciler çoğunlukla duygusal akıl yürütme örüntüsünü kullanmıştır. Öğrencilerin bazıları bazı menülerde sezgisel bir şekilde karar verse de beslenme eğitimi öncesinde mantıksal akıl yürütme örüntüsünü sadece tek bir katılımcı tek bir menü de kullanmıştır. Burada kullandıkları akıl yürütme örüntüleri kendi cümleleri üzerinde detaylıca incelenmiştir.

K-1: Bu portakal suyu herhâlde, çok severim. Ooo sucuk var bayılırım. Yok diğer hiç birini sevmem.

Katılımcı portakal suyunu görür görmez yüzünde bir gülümseme oluşmuştur. Aynı şekilde sucuğu görünce de bayılırım diyerek ne kadar sevdiğini göstermiştir. Diğer besinlere karşı nötr olduğu yüzünden de 
belli olmuştur. Katılımcı menüyü görür görmez duygusal olarak yaklaşmıştır. Seçim yaparken sadece besinleri sevip sevmediği ile ilgilenmiş kendi duygu ve hislerini ön planda tutmuştur.

K-2: Hiçbirini seçmiyorum. Ya da üçüncü menüden patates birinci menüden sucuk seçiyorum.

Burada katılımcı menülerden hiçbirini seçmek istememiştir. Genel olarak yemek seçiciliği olan bir öğrencidir. Menülerin hiçbir özelliğini dikkate almadan sadece kendi sevdiği şeyleri seçme eğilimindedir. Tek bir menü seçmek zorunda olmadığını hissedince rahatlamış, kendi istek ve duyguları doğrultusunda her bir menüden istediği besini seçmiştir. Genelde beslenme tercihi tek yönlüdür. Çeşit besinler yerine her menüde patates arar. Karar verirken sadece zevkleri doğrultusunda karar verdiği için duygusal akıl yürütme örüntüsünü kullanmıştır.

K-5: 3. menüyü seçerim. İşte

Katılımcı menülere direk sezgisel olarak yaklaşmıştır. Menüyü görür görmez hiç düşünmeden istediği menüyü seçmiş sebebini ise açıklamamıştır. Aniden karar verip sebebini gerekçelendiremediği için sezgisel akıl yürütme örüntüsü kullandığı söylemek mümkündür. Seçtiği menüyü neden seçtiği sorulduğunda işte cevabını vermiştir. Bu cevabı çekimserlikten kaynaklanmamıştır. Sadece neden seçtiğini kendisi de ifade edememiştir.

K-4: Kimse kahve içmemeli, benim kardeşim var o içiyor. Ben de bazen kola içebiliyorum ama şimdi yine meyvesuyu olanı seçeceğim çorba da severim.

Katılımcı kimse kahve içmemeli derken sebebini gerekçelendirmeyip seçimini yaparken çorba ve meyve suyunu sevdiği için bu menüye karar verdiğini söylerken sevdiği dışında hiçbir gerekçe sunmadığı için duygusal akıl yürütme örüntüsünü kullandığını göstermiştir. Menüdeki diğer hiçbir besinle ilgilenmeyerek sadece sevdikleri üzerinden konuşmuştur.

K-6: Illk menüyü seçerim peynir, sucuk, börek, zeytin, meyve suyu.

Menüyü görür görmez ilk menüyü seçmek istediğini söyleyen katılımcı neden seçmek istediği sorulduğu halde hiçbir açıklama yapmayıp "işte" cevabını vermiştir. Bu sebeple katılımcının karar verirken sezgisel akıl yürütme örüntüsü kullandığını söylemek mümkündür. Menüler hakkında detaylıca düşünmeden görür görmez karar vermiştir.

K-3: Son menüyü seçiyorum. Çünkü seviyorum.

Katılımcı burada karar verirken sadece kendi arzusunu ön plana koyarak karar vermiştir. Karar verirken kullandığı akıl yürütme örüntüsü duygusaldır. Tüm menüleri incelese de en sevdiği menüyü tercih etmiştir. Kısa ve net açıklamalarla istediğini doğru bir şekilde dile getirmiştir.

K-8: Ay hiç sebze sevmem ya, 2. Menüyü seçerim kola ve köfte.

Katılımcı burada karar verirken sebze sevmediğini dile getirmiştir. Ancak neden sevmediğini gerekçelendirmeyip sadece kendi istekleri doğrultusunda sevdiği besinlerin olduğu menüyü seçerek duygusal akıl yürütme örüntüsünü kullanmıştır. Sevmediği besinleri de göz önünde bulundursa da seçimini en sevdiklerinden yana yapmıştır.

Beslenme eğitimi sonrasında öğrencilerin karar verirken kullandıkları akıl yürütme örüntüleri incelenmiştir. Eğitim sonrası ve öncesinde belirli farklar gözlemlenmiştir. Bu akıl yürütme örüntüleri Tablo 8 'de verilmiş sonrasında detaylıca incelenmiştir.

Tablo 8. Eğitim Sonrası Akıl Yürütme Örüntüleri

\begin{tabular}{cccc}
\hline Katılımcı & Kahvaltı & Öğlen & Akşam \\
\hline K-1 & Mantıksal-Duygusal & Mantıksal & Mantıksal \\
K-2 & Mantıksal-Duygusal & Sezgisel-Duygusal & Mantıksal- Duygusal \\
K-5 & Mantıksal & Mantıksal & Mantıksal- Duygusal
\end{tabular}


Beslenme Eğitiminin Çocukların Beslenme Kararları ve Akıl...

$\begin{array}{cccc}\text { K-4 } & \text { Mantıksal } & \text { Mantıksal- Duygusal } & \text { Mantıksal } \\ \text { K-7 } & \text { Mantıksal } & \text { Mantıksal- Duygusal } & \text { Mantıksal } \\ \text { K-6 } & \text { Duygusal } & \text { Duygusal } & \text { Mantıksal } \\ \text { K-3 } & \text { Mantıksal- Duygusal } & \text { Mantıksal } & \text { Mantıksal } \\ \text { K-8 } & \text { Mantıksal-Duygusal } & \text { Mantıksal } & \text { Sezgisel }\end{array}$

Eğitim öncesi katılımcıların karar verirken çoğunlukla duygusal akıl yürütme örüntüsünü kullanmışlardır. Eğitim sonrasında ise çoğunluk mantıksal ve mantıksal-duygusal akıl yürütme örüntüsünü kullanmışlardır. Katılımcıların kullandıkları akıl yürütme örüntüleri detaylıca incelenmiştir.

K-1: Olabilir. Sucuğu çok seviyorum ama ben sağlıklı olanı yemek istiyorum hem boyum çabuk uzasın birinci sınıfa başlayacağım ben.

Katılımcı burada önce kendi istek ve duygularından bahsederek sucuğu çok sevdiğini dile getiriyor. Önce duygusal akıl yürütme örüntüsüyle yaklaşırken daha sonra sağlıklı olanın sucuk olmadığını dile getirerek mantıksal akıl yürütme örüntüsünü kullanıyor. Ayrıca birinci sınıfa başlayacağı için boyunun uzamasını istediğini ve bunun sağlıklı beslenerek olacağını düşündüğü görülüyor. Burada katılımcı mantıksal duygusal akıl yürütme örüntüsünü kullanmıştır.

K-2: Bence de ikinci menüyü en güzeli. Hem annem de duysa şaşıracak. Hem de yumurta var. Bir de hem beyazı var içinde hem de sarısı. Son menüde patates olsa da ben yine de ikinci menüyü seçeceğim.

Genelde sağlıksız beslenme eğiliminde olan katılımcının sağlıklı olan menüyü seçerken annem duysa şaşıracak demesi ve en sevdiği yiyeceğin patates olduğu halde son menüde patates olsa bile demesi duygularını da ön planda tuttuğunu gösterir. Ancak patatesi çok sevse de yumurtanın daha sağlıklı olduğu için ikinci menüyü seçmesi mantıksal duygusal akıl yürütme örüntüsü kullandığını gösterir.

K-6: Ben sucuktan vazgeçmem zaten babam hafta sonu pişirecek.

Katılımcı karar verirken direk duygusal akıl yürütme örüntüsünü kullanmıştır. Arkadaşlarının sucuk sağlıklı değil demesine karşılık fikrini değiştirmeyen katılımcı duygularıyla karar vermiştir. Kararının duygusal olmasında ailesiyle yaptığı planın büyük bir payı vardır.

K-3: Aslında hepsini de seviyorum. Hepsini de yerim. En çok da yumurtayı yemek istiyorum. Birinci sınıfa gittiğimde boyum da uzun olacak beynim de çalışacak. Ben hep doğruyu biliyorum. Ece bilmiyor zaten yanlış yapıyor.

Katılımcı burada önce duygularından ve sevdiği yiyeceklerden bahsedip boyunun uzun olması ve beyninin gelişmesi için sağlıklı yemesi gerektiğini düşünerek duygusal mantıksal akıl yürütme örüntüsünü kullanmiştır.

K-8: Ben de patatese bayılırım ama artık kızartılmış patates yemeyeceğim. Hem balın da tadın bayılırım. İkinci menüyü yemek istiyorum.

Duygularını bir tarafa bırakmayan katılımcı patatese bayıldığını ancak artık kızartılmış patates yemeyeceğini sağlıklı olduğunu düşündüğü menüdeki balı da çok sevdiğini dile getirerek duygusal mantıksal akıl yürütme örüntüsünü kullanmıştır. Eğitim öncesinde menülere tamamen duygusal yaklaşan katılımcı eğitim sonrasında duygularını sıfırlayamasa da mantıksal düşünmeye başlamıştır.

K-4: Bir kere söylemiştik ya süt içeceğiz iki kere günde. Ben kahvaltıda içeceğim. Hem okulda da içmedik mi. Ben süt olan menüyü istiyorum. Hem yumurtada var.

Katılımcı beslenme eğitiminde öğrendiklerini kararını gerekçelendirerek söylemesi mantıksal akıl yürütme örüntüsünü kullandığının göstergesidir. Kararını gerekçelendirebilmesi ve eğitim sırasında aldığı bilgileri kullanabilmesi katılımcının verimli bir eğitim geçirdiğinin de kanıtıdır.

K-5: Ben en önce de dedim. Ben hep biliyorum sağlıklının hangisi olduğunu kesin benim seçtiğim en iyisi yumurta bile var. 
Katılımcının direk mantıksal akıl yürütme örüntüsünü kullandığı görülmüştür. Sağlıklı olduğu için bu menüyü seçtiğini belirtmiştir. Aldığı beslenme eğitiminde yumurtanın faydalarını öğrendiğinden özellikle yumurta olduğu için seçtiği menünün en iyisi olduğunu dile getirmiştir. Aynı zamanda başarılı olma arzusu da taşımaktadır.

K-7: Ben de hep patates istiyordum ama şimdi yumurta yiyeceğim. Hem Bilgin vardı ya o ne diyordu. Ben bunu hatırliyorum. Yumurta yemek istiyorum.

Burada katılımcı eskiden patatesi isterken şimdi yumurtanın olduğu menüyü istediğini dile getirmiştir. Aldığı eğitimlerle gerekçelendirerek mantıksal akıl yürütme örüntüsünü kullanmıştır. Aynı zamanda katılımcı kendindeki değişimin de farkındadır. Eskiden olsa patates seçeceğini de belirtmiştir.

K-4: En sağlıklı içeceklerden bol bol köpük köpüklü ayran pilav bide etlerle sebzelerin olduğu yemeği çok seviyorum.

Zaten en çok benim uzun diye en doğruları hep ben bilirim. Ben sağlıklı yerim her zaman

Katılımcı burada duygusal mantıksal akıl yürütme örüntüsünü kullanmıştır. Duygu ve düşüncelerini geri plana atmadan besinleri sevdiğinden bahsedip, boyunun uzun olmasını sağlıklı ve bilinçli olduğuna bağlamıştır. Ayrıca karar verirken besinleri hem sevdiği için hem de sağlıklı olduğunu düşündüğü için seçmiştir.

K-5: İçinde sebzeler var etler var bu çok sağlıklı bir yemek olmuş. Zaten hem et hep sebze yememiz gerekir.

Katılımcı burada karar verirken direk mantıksal akıl yürütme örüntüsünü kullanmıştır. Menüyü seçme sebebinin sağlıklı olduğunu açıç̧a dile getirmiştir. Seçimini yaparken başarılı olduğunu düşünen gururlu bir yüz ifadesi kullanmıştır.

K-2: Ben dolma olan menüyü seçeceğim canım böyle istiyor.

Katılımcı burada hiç düşünmeden direk cevap vererek sezgisel yaklaşmış ancak sebebi sorulunca canım böyle istiyor diye cevap vermiştir. Son kararını verirken sezgisel duygusal akıl yürütme örüntüsünü kullanmıştır. Genel olarak yemeklere karşı olumlu bir tutumda olmayışı bu seçimin sezgisel olmasına sebep olmuştur. Menüdeki besinleri sevmediği ve sağlıklı olup olmadığıyla da ilgilenmediğinden aklına ilk gelen menüyü seçmiştir.

K-6: Ben de K-2 gibi dolma olan menüyü seçeceğim. Tadı mis gibi yanında sıcacık çorba da var.

Katılımcı karar verirken kendisinden bir önce konuşan arkadaşından etkilenmiş ve mis gibi sıcacık diyerek duyguların belirtmiştir. Karar duygusal akıl yürütme örüntüsünü kullanmıştır. Genel olarak duygusal bir yapıya sahip olan katılımcı arkadaşından etkilendiğini söylerken de sevimli bir yüz ifadesiyle arkadaşına gülümsemiştir.

K-7: Hiçte bile. Bir kere sebze ve et çok sağlıklı. Ben pilav da çok severim. Ben ilk menüyü seçiyorum.

Katılımcı öncelikle mantıksal olarak yaklaşmış, sağlıklı olduğu için menüyü tercih ettiğini söylemiştir. Ancak yemeği sevdiğini söyleyerek duygularını da geri plana atmadığından karar verirken duygusal mantıksal akıl yürütme örüntüsünü kullanmıştır.

K-1: Bize Bilginin neler anlattığını herkes unutmuş herhalde. Tabi ki ilk menüyü seçeceğim. En sağlıklısı en doğrusu bu.

Katılımcı burada karar verirken aldığı eğitimlerden etkilenmiş ve direk mantıksal akıl yürütme becerisini kullanmıştır. Aldığı eğitimleri kullanarak kararını gerekçelendirmesi eğitimi başarılı bir şekilde geçirdiğinin göstergesidir.

K-8: Bir kere çorba da çok sağlıklı hem dolma da sebze. Ben üçüncü menüyü seçeceğim o da çok sağlıklı değil mi öğretmenim.

Katılımcı karar verirken sağlıklı olan menüyü seçmeye çalışmış ve mantıksal akıl yürütme örüntüsünü kullanmıştır. Ancak seçerken kendinden çok da emin olmayarak değil mi öğretmenim diyerek teyit ettirmek istemiştir. Sağlıklıyı seçmeye çalışmıştır. Pandemi sebebinden dolayı bazı eğitimlere katılamaması net bir duruş sergilemesinde etkilidir.

K-3: Ben hep doğruları bilirim öğretmenim sebzeli kuşbaşı bu kesin. Sağlıksız olsa okulda da yapılmaz bi kere biz de okulda pilav ayran bundan yemedik mi. O yüzden ben kesin sağlıklıyı seçeceğim. 
Katılımcı burada seçim sebebini gerekçelendirerek sağlıklı menüyü seçme eğiliminde olduğunu göstermiştir. Okulda aynı yemekler çıktığına göre kesin sağlıklıdır çıkarımını yaparak mantıksal akıl yürütme örüntüsünü kullanmıştır. Hem aldığı beslenme eğitiminden etkilenmiş hem de okulunda sağlıklı yemekler piştiği konusunda bilgili olduğu için kendinden emin bir şekilde cevaplamıştır.

K-6: Kuru baklagilin faydasını ben unutmadım ben kuru fasulye olanı seçiyorum.

K-1: Tabi ki en sağlıklı olanı seçeceğim ben kuru fasulye kuru baklagil grubuydu ben de eceye katılıyorum yememiz gerekli ben bunu seçiyorum.

İki katılımcı da karar verirken direk mantıksal akıl yürütme örüntüsünü kullanmıştır. Seçtikleri menüyü sağlıklı olduğu için tercih ettiklerini belirtmiştir. Katılımclardan Ece seçtiği menüdeki besinlerden birinin hangi besin grubuna ait olduğunu hatırlayınca direk karar vermiş, K-1 ise bu besin grubunu tüketmemiz gerekirdi diye arkadaşına katılarak sağlıklı yönünde tercihlerini yapmışlardır.

K-5: Ben hiç karnabahar yemedim makarna da severim enerji veriri. Ben karnabahar olan menüyü seçeceğim.

Katılımcı daha önce hiç karnabahar yemediğini söylemiştir. Karnabaharın tadını merak etmesi duygusal yaklaştığını gösterirken, makarnanın enerji verdiği için bu menüyü tercih ettiğini söylemesi aldığı beslenme eğitiminin sonucudur. Katılımcı karar verirken duygusal mantıksal akıl yürütme örüntüsünü kullanmıştır. Hem merakını giderip hem de sağlıklı olan bir seçim yapmak istemiştir.

K-8: Evet bence de hem sebze çorbası da var bende karnabaharlı menüyü seçiyorum.

Katılımcı burada hiçbir açıklama ve gerekçelendirme yapmadan birden cevap verdiği için sezgisel akıl yürütme örüntüsünü kullandığı söylenebilir.

K-3: Kuru fasulyede et de var bide pilavla cacık var. Hem biliyor musunuz cacık yoğurttan yapılıyor süt ürünü var et var kurubaklagil var ben kesin fasulyeli menüyü istiyorum.

K-7: Ben de kuru fasulye pilav cacık menüsünü seçiyorum öğretmenim. En sağlıklısı bu menü bence ben de sağlıklı besleniyorum artık.

K-4: Öğretmenim ben çok iyiyim demi hep biliyorum şimdi de fasulyeli menüyü istiyorum. Zaten bu kadar uzun olmazdım ki bilmeseydim bir de beynim bu kadar çalışmazdı. Ben çok güzel yediğim için hep böyle oldu.

Katılımcılar burada aldıkları beslenme eğitimini de göz önünde bulundurarak sağlıklı olduğu için tercih yaptıklarını belirtmişlerdir. Mantıksal akıl yürütme örüntüsünü kullanmışlarıdır. Hem besinlerin hangi gruplara ait olduğunu hem de faydalarını dile getirmişlerdir. Seçim yaparken oldukça kendilerinden emin özgüvenli bir tavır sergilemişlerdir. Sağlıklı beslenme eğiliminde oldukları için kendilerinde olumlu değişiklikler olacağını hisseden konuşmalar yapmışlardır. Beslenme eğitiminin kendilerine fayda sağladığını gösterirken gururlu ve ne istediklerini bilen bireyler olmaları dikkat çekmiştir. Eğitim öncesinde tedirgin davranan katılımcıların özgüvenlerinde de görülür bir şekilde olumlu değişiklikler meydana gelmiştir.

Eğitim öncesinde ve sonrasında kullanılan akıl yürütme örüntüleri değişiklik göstermiştir. Şekil II'de beslenme eğitimi öncesinde ve eğitim sonrasında katılımcıların karar verirken kullandıkları akıl yürütme örüntülerindeki değişim gösterilmiştir. Sonrasında detaylıca anlatılmıştır. 


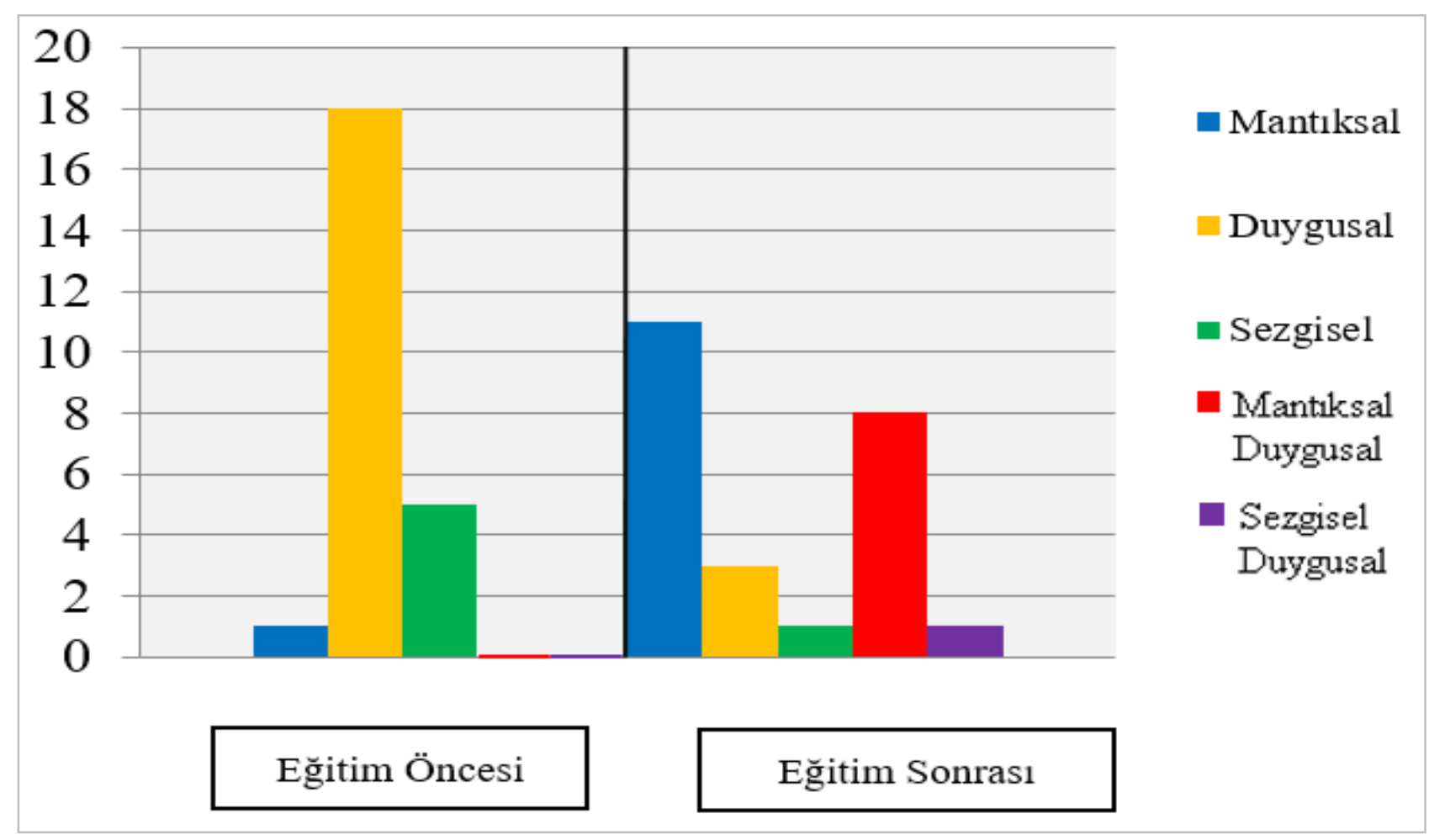

Şekil 2. Akıl Yürütme Örüntülerinin Değissimi

Verilen beslenme eğitimi öncesinde katılımcıların karar verirken kullandıkları akıl yürütme örüntülerinin çoğunlukla duygusal yönde olduğu belirlenmiştir. Büyük oranda duygusal akıl yürütme örüntüsünü kullanan katılımcılar ikinci sırada ise sezgisel akıl yürütme örüntüsünü kullanmışlardır. Beslenme eğitimi sonrasında ise katılımcıların büyük kısmı mantıksal akıl yürütme örüntüsünü kullanırken ikinci sırada mantıksal duygusal akıl yürütme örüntüsünü kullandıkları belirlenmiştir. Buradan anlaşılacağı üzere okul öncesi dönem çocuklarının genel olarak duygusal akıl yürütme örüntüsünü kullanmaktadırlar. Ancak aldıkları eğitimle mantıksal yöne kaysalar dahi duygularını tamamen yok saymaları imkânsızdır.

Katılımcıların kullandıkları akıl yürütme örüntüleri eğitim öncesi ve eğitim sonrası olmak üzere büyük bir değişiklik göstermektedir. Katılımcıların toplamda hangi akıl yürütme örüntüsünden kaç tane kullandığı belirlenmiştir. Tablo 9'da incelenmiştir. Sonrasında detaylıca yorumlanmıştır.

Tablo 9. Akıl Yürütme Örüntülerinin Miktarı

\begin{tabular}{|c|c|c|c|c|c|c|}
\hline Durum & Mantıksal & Duygusal & Sezgisel & $\begin{array}{l}\text { Mantıksal } \\
\text { Duygusal }\end{array}$ & $\begin{array}{c}\text { Sezgisel } \\
\text { Duygusal }\end{array}$ & Toplam \\
\hline Eğitim Öncesi & 1 & 18 & 5 & 0 & 0 & 24 \\
\hline Eğitim Sonrası & 11 & 3 & 1 & 8 & 1 & 24 \\
\hline Toplam & 12 & 21 & 6 & 8 & 1 & 48 \\
\hline
\end{tabular}

Eğitim öncesinde sadece biz kez kullanılan mantıksal akıl yürütme örüntüsü eğitim sonrasında on bir kez kullanılarak toplam on iki kez kullanılmıştır. Mantıksal duygusal akıl yürütme örüntüsü ise eğitim öncesinde hiç kullanılmazken eğitim sonrasında sekiz kez kullanılmıştır. Eğitim öncesinde on sekiz kez kullanılan duygusal akıl yürütme örüntüsü eğitim sonrasında sadece üç kez kullanılmıştır. Eğitim öncesinde beş kez kullanılan akıl yürütme örüntüsü eğitim sonrasında sadece bir kez kullanılmıştır. En az kullanılan akıl yürütme örüntüsü olan sezgisel duygusal akıl yürütme örüntüsü sadece bir kez kullanılmıştır. Toplamda en çok kullanılan akıl yürütme örüntüsü duygusal akıl yürütme örüntüsü iken ikinci sırada mantıksal akıl yürütme örüntüsü vardır. Mantıksal akıl yürütme örüntüsü toplam sekiz kez kullanılmıştır. Bunu toplamda sekiz kez kullanılan mantıksal duygusal akıl yürütme örüntüsü takip etmiştir. Sezgisel akıl yürütme örüntüsü 
altı, sezgisel duygusal akıl yürütme örüntüsü ise bir kez kullanılmıştır. Tabloya genel olarak bakıldığı zaman eğitim öncesi ve sonrası toplam kullanılan akıl yürütme örüntülerinin en yüksek olanının duygusal olmasının sebebi eğitim öncesinde genel olarak çoğu çocuğun duygusal boyutta yaklaşmasıdır. Eğitim sonrasında ise mantıksal akıl yürütme örüntüsü duygusal akıl yürütme örüntüsüne göre daha fazladır. Buna rağmen toplamda mantıksal akıl yürütme örüntüsü duygusal akıl yürütme örüntüsünden daha azdır. Bunun sebebi, erken çocukluk dönemindeki çocukların karar verirken mantıklı akıl yürütme örüntüsü kullansalar da duygularını geri plana atamamaktadırlar. Bu sebeple seçimlerde sekiz kez duygusal mantıksal akıl yürütme örüntüsü kullanılmıştır.

\section{Sonuç ve Tartışma}

$\mathrm{Bu}$ araştırmada okul öncesi dönem çocuklarına verilen beslenme eğitiminin çocukların beslenme davranışının ve karar verirken kullandıkları akıl yürütme örüntülerinin nasıl değiştiğini incelemiştir. Durum çalışmasıyla gerçekleştirilen bu araştırmaya sekiz okul öncesi öğrencisi katılmıştır. Bu öğrencilerin beslenme eğitiminden önce ve sonra olmak üzere, beslenme tercihleri ve menü seçimlerine karar verirken kullandıkları akıl yürütme örüntüleri analiz edildikten sonra ulaşılan sonuçlar aşağıda maddeler halinde verilmiştir.

1. Beslenme eğitimi öncesinde sağlıksız beslenme eğiliminde olan çocuklar beslenme eğitimi sonrasında sağliklı beslenme eğiliminde olmuşlardır

2. Beslenme eğitimi çocukların menü seçiminde daha mantıklı kararlar vermelerine neden olmuştur.

3. Beslenme eğitimi öncesinde çocuklar daha çok duygusal karar verme eğilimindedirler.

4. Beslenme eğitimi sonrasında çocukların informal akıl yürütme örüntülerinde mantıksal yönler daha ağır basmıştır.

Araştırmanın bu bölümünde ulaşılan sonuçlar, ilgili literatür ışığında tartışılmıştır. Kuramsal temellerde sunulan çalışmalarda elde edilen sonuçlar da göz önünde bulundurulmuştur. Benzer ve benzer olmayan sonuçların nedenleri alt başlıklar altında tartışılmıştır.

\section{Çocukların Beslenme Kararları}

Sağlıklı beslenme alışkanlığının temeli çocukluk döneminde atılır. Okul öncesi eğitim döneminde verilen beslenme eğitimi bireyin yaşam boyu sağlığı açısından büyük önem taşır (Dietz, 2004). Sağlıklı beslenme, yaşam kalitesinin artması ve sağlıklı uzun bir yaşam için gerekli olan en önemli faktörlerden biridir (Lanuza ve diğerleri, 2020). Sağlıklı beslenmenin temelinde ise, nasıl beslenileceğini bilmek ve doğru beslenme tercihleri yapabilmek vardır (Black ve Heidkamp, 2018). Erken yaşlarda verilen beslenme eğitimi ileriki yaşlarda oluşacak hastalıkları önlemek açısından önemli bir yere sahiptir (Dahm ve diğerleri, 2016). Bu bağlamda çocukların beslenme tercihleri oldukça önemlidir. Bu araştırmada gerçekleştirilen analizler sonucunda, beslenme eğitimi öncesinde yapılan seçimlerde çocukların genel olarak sağlıksız beslenme eğiliminde oldukları görülmüştür (Tablo 4). Bu durumun sebebi çocukların daha önce beslenme eğitimi almamış olmasıdır. Öğrencilerin daha önce beslenme eğitimi almamış olmaları, yeni verilecek eğitimin etkinliğini etkilemektedir (Tallon ve diğerleri, 2020). Onbaşı (2017), Uzşen (2016) ve Sabbağ, (2011) okullarda yaptıkları beslenme eğitimi araştırmalarında katılımcıların yarısından daha fazlasının daha önce beslenme eğitimi almadığını belirtmiştir. Yapılan çalışmaların sonuçları da bu araştırmanın sonucunu destekler nitelikte olup çalışma öncesinde öğrencilerin beslenme konusunda eğitimsiz olduğunu göstermektedir. Yapılan çalışmaların verilerine göre beslenme ile ilgili yapılan çalışmaların hala yeterli olmadığı söylenebilir. Bunun sebebinin ise okullarda öğretmenler tarafından bu eğitimlerin verilmemesi ve müfredatta böyle bir eğitimin bulunmamasıdır. Bu sonuç yapılan çalışmalarla da desteklenmektedir. Öğretmenler üniversitede yeterli düzeyde eğitim almadıkları için kendilerini yetersiz hissettiklerini ve öğrencilere beslenme eğitimi verme konusunda isteksiz ve yetersiz oldukların belirtmişlerdir (Aldubayan, 2020; Li ve diğerleri, 2020). Beslenme konusunda herhangi bir eğitim almayan öğrencilerin beslenme kararlarının sağlıksız yönde olması normal karşılanabilir bir durumdur. Genel olarak çocukların eğitim öncesinde verdikleri sağlıksız kararlar düşünülmeden direk sevdikleri yiyecekleri seçmeleri yönünde olmuştur. 
Erken çocukluk dönemi beslenme eğitimi verebilmek için en uygun dönemdir. Yaş grubu olarak küçük oldukları düşünülse de yapılan araştırmalar küçük yaş gruplarında olumlu dönüşler alındığını göstermektedir. Tatlow-Golden ve diğerleri, (2013) çalışmalarında çocukların dört yaşından itibaren besinlerle sağlığı ilişkisini kurabildiğini göstermiştir. Contento ve diğerleri (1995) yaptıkları çalışmada, üç-beş yaş arasındaki çocuklarının besinleri tanıyabildiklerini, besin öğesi ve enerji içeriklerini kavrayabildiklerini ve beslenme eğitiminin beslenme ile ilgili kavramlara ilişkin bilgisini geliştirdiği sonucuna varmıştır. Zarnowiecki, Dollman ve Sinn (2011) beş-altı yaş çocukların beslenme eğitimi için uygun yaşta oldukları ve çocukların sağlıklı besinleri doğru şekilde belirleyebildikleri saptanmıştır. Tüm bu çalışmalar araştırmamızı destekler nitelikte olup okul öncesi dönem çocuğuna verilen doğru beslenme eğitimlerinin olumlu sonuçlandığını göstermektedir.

Bu çalışmada dikkat çeken bir diğer unsur ise eğitim öncesinde beslenme kararlarının bireysel ve grupla verilmesi yönündedir. Henüz beslenme anlamında hiçbir eğitim verilmemişken aynı hafta içerisinde aynı menüler sunulduğu halde katılımcıların bazılarının farklı kararlar verebildikleri görülmüştür (Tablo 5). Bunun sebebi ise okul öncesi dönem çocuklarının akranlarının fikirlerinden etkilenmesidir. Bazı öğrencilerin kararlarının değişmemesi karakter özellikleri ve bireysel farklılıklardan kaynaklanmaktadır. Okul öncesi dönem çocuklarının akranlarından olumlu ve olumsuz davranışları öğrenebildikleri söylenmektedir (Schwartz, Dodge, Petit ve Bates, 2000). Bu araştırmada da çocuklar genel olarak akranlarından olumlu yönde etkilenerek sağlıklı beslenme yönüne doğru kaymışlardır.

Çocuklar günlerinin büyük bir kısmını okulda geçirdikleri için okulda yapılan beslenme etkinlikleri çocukların beslenme kararlarını etkilemektedir (Arcan ve diğerleri, 2013). Okullarda düzenlenen beslenme etkinlikleri, çocukların sağlıklı yaşam sürmeleri ve sağlıklı tercihler yapabilmeleri için önemli fırsatlardandır (Briggs, Fleischhacker ve Mueller, 2010). Yapılan çalışmalarda okuldaki eğitimlerle okul öncesi dönem çocuklarının beslenme seçimleri ve evdeki beslenme davranışları olumlu yönde değişebileceği ortaya konmuştur (Kobak, 2009). Yaptığımız çalışmada zamanlarının büyük kısmını okulda geçiren katılımclara verilen beslenme eğitiminin katılımcıların beslenme tercihlerini olumlu yönde değiştirdiğini göstermiştir. (Tablo 9). Erol (2017) ve Jung, Huang, Eagan ve Oldenburg'un (2019) yaptıkları çalışmalar da bu araştırmayı destekler nitelikle olup verilen beslenme eğitimlerinin çocukların beslenme tercihlerinde olumlu bir sonuca ulaştığını göstermektedir. Çalışmamızda olduğu gibi çocukların severek etkinliklere katıldığı bazen bazı etkinlikleri tekrar yapmak istedikleri de göz önünde bulundurulduğu zaman doğru ve zamanında verilen beslenme eğitimi çocukların beslenme tercihlerini doğru yönde etkileyecektir.

\section{Çocukların Beslenme Kararlarına İlişskin Akıl Yürütme Örüntüleri}

Çalışmanın bu aşamasında katılımcıların beslenme eğitiminden önce ve beslenme eğitiminden sonraki karar verme süreçleri incelenmiştir. Çalışmamızda verilen beslenme eğitimi öncesinde katılımcıların karar verirken kullandıkları akıl yürütme örüntülerinin çoğunlukla duygusal yönde olduğu belirlenmiştir (Tablo 7). Büyük oranda duygusal akıl yürütme örüntüsünü kullanan katılımcılar ikinci sırada ise sezgisel akıl yürütme örüntüsünü kullanmışlardır. Mantıksal akıl yürütme örüntüsü ise sadece bir öğrenci tarafından tek bir öğünde kullanılmıştır. Öğrencilerin beslenme eğitimi anlamında bir ön bilgileri olmadığı bilindiği için mantıksal kararların az olması beklenen bir sonuçtur. Karamanlı (2019) yaptığı çalışmasında haftalar içerisinde öğrencilerin akıl yürütme örüntülerindeki değişimleri incelemiştir. Aynı bu araştırmada olduğu gibi ilk iki haftada duygusal ve sezgisel akıl yürütme örüntüsünün son haftalara oranla daha fazla olduğunu saptamıştır.

Beslenme eğitimi sonrasında ise katılımcıların büyük kısmı mantıksal akıl yürütme örüntüsünü kullanırken ikinci sırada mantıksal duygusal akıl yürütme örüntüsünü kullandıkları belirlenmiştir (Tablo 8). Eğitim sonrası öğrencilerin mantıksal akıl yürütme örüntüsü kullanmaları eğitimin verimli geçtiğini ve öğrencilerin bir konuda bilgi sahibi olmalarının karar verme konusunda daha mantıklı yaklaşabildiklerini göstermektedir. Akbaş ve Çetin (2018) yaptıkları çalışmada çalışma süresince mantıksal akıl yürütme örüntülerinin artış gösterdiği sonucuna ulaşmıştır. Bu araştırmada da altı haftalık eğitimin başlangıcında duygusal yönde karar veren öğrenciler eğitim sonunda mantıksal yönü ağır basan kararlar vermişlerdir. 
Sadler ve Fowler (2006) tarafından yapılan çalışma da çalışmamızı destekler niteliktedir. 45 öğrenci üzerinde yaptıkları bu araştırmada öğrencilere gen terapisi ve klonlama ile ilgili üç farklı sosyobilimsel konulara yönelik senaryolar sunmuşlardır. Argümantasyonlarının kalitesini ve gerekçelendirme kalitelerini ölçek sayesinde belirlemişlerdir. Sonuçlarda ise alan bilgisine sahip olanların argümantasyon ve gerekçelendirme kalitelerinin daha kaliteli olduğu belirtilmiştir. Bu çalışmada olduğu gibi herhangi bir konuda eğitim alan çocukların akıl yürütme örüntülerinin ve argümantasyon kalitelerinin olumlu yönde değişiklik gösterdiği söylenebilir. Ayrıca, Aydın ve Kaptan (2014) yaptıkları çalışmanın sonucu da bu araştırmayı destekler nitelikte olup, fen derslerinin argümantasyona dayandırılarak işlemesinin sonucunda öğrencilerin mantıksal yorumlama becerilerinin ve mantıksal akıl yürütme örüntülerinin artış gösterdiğini saptamıştır. Ancak çalışmamızda eğitim sonrası en çok kullanılan akıl yürütme örüntüsü olan mantıksal akıl yürütme örüntüsünü takip eden mantıksal-duygusal akıl yürütme örüntüsü azımsanamayacak kadar çok öğrenci tarafından kullanılmıştır. Bu durum çalışmamızı diğer çalışmalardan ayıran en önemli farktır. Eğitimin verimli ve eğlenceli geçmesine rağmen hala duygusal yönlerin ağır basması çalışılan yaş grubu ile alakalı bir sonuçtur. Çünkü çocuklar Piaget'in bilişsel gelişim dönemlerine göre dört-yedi yaş arasında sezgisel dönem içerisindedir. Sezgisel dönemde olan çocuklar mantıksal düşünceden daha çok duygusal ve sezgisel düşüncede olurlar. Çocukların zihinsel gelişimi ile karar verme becerileri arasındaki ilişkiyi inceleyen başka bir çalışmada, beş-altı yaşlarında çocukların, zihinsel gelişimlerine paralel olarak karar verme durumlarıyla fazla karşılaşmalarının çocukların karar verme becerileri, bağımsızlık becerileri, iletişim becerileri ve duygusal gelişimlerini güçlendirdiği bulgusuna ulaşılmıştır (Mata, Sallum, Moraes, Miranda ve Malloy-Diniz, 2013). Garon ve Moore (2004), okul öncesi dönemde çocukların yaşları arttıkça, anlama kapasitelerinin arttığını, karar verme durumlarında daha fazla seçenek ürettikleri ve seçim yaparken daha çok düşündüklerini, dolayısıyla karar verme becerilerinin geliştiğini belirtmiştir. Özden, (2020) İlkokul öğrencilerinin sosyobilimsel konulara ilişkin informal akıl yürütme örüntülerinin incelenmesi çalışmasında diğer araştırmalardan daha farklı bir sonuç bulmuştur. Bu çalışmaya göre en çok kullanılan akıl yürütme örüntüsünün sezgisel en az kullanılan akıl yürütme örüntüsünün ise mantıksal akıl yürütme örüntüsüdür. Bu çalışmada sadece bilişsel değil duyuşşal düşünme becerileri üzerinde de durulmuştur. Yapılan çalışma ile bu araştırmadaki katılım grubunun yaşlarının birbirine yakın olması mantıksal akıl yürütme örüntüsünün en çok kullanılan akıl yürütme örüntüsü olmamasının göstergesidir.

Araştırma sonucunda dikkat çeken bir diğer nokta ise informal akıl yürütme becerilerinin yaşlara göre değişiklik göstermesidir. Örneğin bu araştırmada okul öncesi yaş grubu duygusal karar verme eğilimindeyken, altıncı ve sekizinci sınıfa giden öğrencilere aynı konuda (hidroelektrik santraller ve plastik atıklar ve geri dönüşüm) çalışmalar yapıldığında altıncı sınıf öğrencileri sezgisel yaklaşırken 8 . Sınıf öğrencileri mantıksal yaklaşmışlardır. Venville ve Dawson (2010) bunu kanıtlayan bir çalışma yapmışlardır. 12 ile 17 yaş arasındaki çocukların informal muhakeme yeteneklerini incelemişlerdir. Yaş grubuna göre mantıksal akıl yürütme yerine sezgisel akıl yürütme yaptıkları sonucuna ulaşmışlarıdır.

Çalışmanın en sonunda ise eğitimin başından sonuna kadar kullanılan akıl yürütme örüntüleri incelenmiştir. Eğitim öncesinde duygusal akıl yürütme örüntüleri baskınken eğitim sonunda mantıksal akıl yürütme örüntüleri ağırlıklı durumdadır. Eğitim süresince ise en çok kullanılan akıl yürütme örüntüsü duygusal akıl yürütmedir. Akabinde ise mantıksal akıl yürütme örüntüsü gelmiştir. Bunu mantıksal duygusal akıl yürütme örüntüsü takip ederken sonrasında sezgisel akıl yürütme örüntüsü kullanılmıştır. Eğitim boyunca en az kullanılan akıl yürütme örüntüsü ise sezgisel-duygusal akıl yürütme örüntüsüdür (Tablo 9). Yapılan çalışmanın çoğunda mantıksal akıl yürütme örüntüleri fazlayken bu çalışmada duygusal akıl yürütmenin fazla olması çalı̧̧mamızın erken çocukluk dönemi içerisinde olan çocuklar üzerinde yapılmış olmasıdır. Çocuklar, problem çözmeye başlarken belirsizliklerle işe başlarlar, karar verme, tahmin ve inceleme yöntemlerini kullanırlar. Bu belirsizlikler merakın artması ve araştırma gibi durumları ortaya çıarır (Zembat ve Unutkan, 2005). Literatürdeki bu yapılmış çalışmalar incelendiğinde çalışmamızda olduğu gibi eğitim sonrasında mantıksal akıl yürütme örüntüsünün duygusal akıl yürütme örüntüsüne göre daha fazla olduğu daha net açılanabilmektedir. Bu bağlamda çocukların beslenme kararlarına ilişkin akıl yürütme örüntüleri, verilen beslenme eğitimi ile çocukların karşılaştığı güçlüklere kendi başına çözüm yolu aramaları, bilgi ve becerilerini kullanmaları iyi bir problem çözücü olmalarının yanı sıra karar verme becerilerini de geliştirmiştir. 


\section{Öneriler}

$\mathrm{Bu}$ araştırmada elde edilen sonuçların literatür ile tartışılması sonucunda yapılan öneriler aşağıda verilmiştir.

1. Kurumlardaki öğretmenler ve okul yönetimi, çocukların yaş ve gelişim düzeylerine uygun beslenme programları oluşturabilirler. Bunun için üniversitelerin ilgili bölümleri ve Sağlık Bakanlığı ile Millî Eğitim Bakanlığıyla ortak çalışmalar yürütülebilir.

2. Beslenme eğitimi ile ilgili aile katılımı çalışmalarının arttırılması sağlanabilir.

3. Çocukların takip ettiği çocuk kanallarındaki yayın akışlarına; doğru, yeterli ve dengeli beslenmeye yönelik animasyonlara, çizgi filmlere ve çocuk şarkılarına daha fazla yer verilebilir.

4. Beslenme bağlamında okul öncesi öğretmen ve öğretmen adaylarının ve ebeveynlerin karar ve akıl yürütme örüntülerinin keşfedilmesine ilişkin yeni araştırmalar gerçekleştirilebilir.

5. Beslenme eğitiminin okul öncesi eğitim müfredatlarına doğrudan dâhil edilebileceği uygulamalar yapilabilir.

\section{Yazarların Beyanı}

Araştırmacıların katkı oranı beyanı: Bu araştırma birinci yazarı "Beslenme Ĕ̆itiminin Okul Öncesi Öğrencilerinin Beslenme Davranışları ve Karar Verme Faktörleri Üzerine Etkisinin İncelenmesi" başlkkl yüksek lisans tezinden üretilmiştir. Bu makalenin oluşturulması sürecinde her iki yazarın da eşit katkısı bulunmaktadır.

Etik Kurul Kararı: Bu araştırma İstanbul Aydın Üniversitesi 31.08.2020 tarihli E-88083623-020 sayıl karar kapsamında araştırma etik kurallarına uygundur.

Çatışma beyanı: Bu çalışmada her iki yazar da ortak katkıya sahip oldukları için herhangi bir çatışma veya görüş ayrılığı bulunmamaktadır

Destek ve teşekkür: Bu araştırmanın gerçekleştirilmesindeki katkılarından dolayı İstanbul Aydın Üniversitesi Lisansüstü Ĕ̆itim Enstitüsüne teşekkür ederiz.

\section{Kaynaklar}

Adal, E. E. (2019). Investigation of preservice science teachers' nature of science understanding and decision making on socioscientific issue through the fractal model (Yayınlanmamış doktora tezi). Orta Doğu Teknik Üniversitesi, Ankara.

Akbaş, M., \& Çetin, P. S. (2018). The investigation of gifted students' argumentation level and informal reasoning related to socioscientific issues. Necatibey Faculty of Education Electronic Journal of Science $\mathcal{E}$ Mathematics Education, 12(1), 339-360.

Albe, V. (2008). When scientific knowledge, daily life experience, epistemological and social considerations intersect: Students' argumentation in group discussions on a socio-scientific issue. Research in Science Education, 38(1), 67-90.

Aldubayan, K. (2020). Teachers' perspectives on nutrition education in boys' public high schools in Riyadh, Saudi Arabia. Eastern Mediterranean Health Journal, 26(2), 170-175.

Arcan, C., Hannan, P. J., Himes, J. H., Fulkerson, J. A., Rock, B. H., Smyth, M., \& Story, M. (2013). Intervention effects on kindergarten and first-grade teachers' classroom food practices and food-related beliefs in American Indian reservation schools. Journal of the Academy of Nutrition and Dietetics, 113(8), 1076-1083.

Aydın, Ö., \& Kaptan, F. (2014). Fen-teknoloji öğretmen adaylarının eğitiminde argümantasyonun biliş üstü ve mantıksal düşünme becerilerine etkisi ve argümantasyona ilişkin görüşler. Eğitim Bilimleri Araştırmaları Dergisi, 4(2), 163-188.

Baltacı, A. (2019). Nitel araştırma süreci: Nitel bir araştırma nasıl yapılır?. Ahi Evran Üniversitesi Sosyal Bilimler Enstitüsü Dergisi, 5(2), 368-388. 
Başkale, H. (2016). Determination of validity, reliability and sample size in qualitative studies. Dokuz Eylül Üniversitesi Hemşirelik Fakültesi Elektronik Dergisi, 9(1), 23-28.

Berge, J. M. (2009). A review of familial correlates of child and adolescent obesity: what has the 21st century taught us so far?. International Journal of Adolescent Medicine and Health, 21(4), 457-483.

Birch, L. L., \& Doub, A. E. (2014). Learning to eat: birth to age 2 y. The American Journal of Clinical Nutrition, 99(3), 723-728.

Black, R. E., \& Heidkamp, R. (2018). Causes of stunting and preventive dietary interventions in pregnancy and early childhood. Colombo J., Koletzko B. \& Lampl M. (Ed.), Recent Research in Nutrition and Growth (s. 105113) içinde. Karger Publishers.

Bredekamp, S. (2015). Effective practices in early childhood education: Building a foundation. Upper Saddle River, NJ: Pearson.

Briggs, M., Fleischhacker, S., \& Mueller, C. G. (2010). Position of the American dietetic association, school nutrition association, and society for nutrition education: Comprehensive school nutrition services. Journal of Nutrition Education and Behavior, 42(6), 360-371.

Chen, L. C., Chen, Y. H., \& Ma, W. I. (2017). Effects of integrated information literacy on science learning and problem-solving among seventh-grade students. Malaysian Journal of Library \& Information Science, 19(2), 35-51.

Contento, I., Balch, G. I., Bronner, Y. L., Lytle, L. A., Maloney, S. K., Olson, C. M., \& Swadener, S. S. (1995). Theoretical frameworks or models for nutrition education. Journal of Nutrition Education, 27(6), 287-90.

Creswell, J. W. (2003). Research design: qualitative, quantitative and mixed methods approaches. California: Sage Publications.

Creswell, J. W., \& Poth, C. N. (2016). Qualitative inquiry and research design: Choosing among five approaches. Sage Publications.

Çapkınoğlu, E. (2015). 7. sını öğrencilerinin yerel sosyobilimsel konularda oluşturdukları argümantasyonların kalitesi ve karar verirken dikkate aldıkları faktörlerin incelenmesi (Yayınlanmamış Doktora Tezi). Hacettepe Üniversitesi, Ankara.

Dahm, C. C., Chomistek, A. K., Jakobsen, M. U., Mukamal, K. J., Eliassen, A. H., Sesso, H. D., ... \& Chiuve, S. E. (2016). Adolescent diet quality and cardiovascular disease risk factors and incident cardiovascular disease in middle-aged women. Journal of the American Heart Association, 5(12), 35-83.

Davies, D., Howe, A., Collier, C., Digby, R., Earle, S., \& McMahon, K. (2003). Teaching science, design and technology in the early years. David Fulton Publishers.

Dawson, V., \& Venville, G. (2020). Testing a methodology for the development of socioscientific issues to enhance middle school students' argumentation and reasoning. Research in Science \& Technological Education, 1-16. https://doi.org/10.1080/02635143.2020.1830267

Dawson, V., \& Venville, G. J. (2009). High-school Students' Informal Reasoning and Argumentation about Biotechnology: An indicator of scientific literacy?. International Journal of Science Education, 31(11), 14211445.

Demirtaş, V. Y., \& Sucuoğlu, H. (2009). In the early childhood period children's decision-making processes. Procedia-Social and Behavioral Sciences, 1(1), 2317-2326.

Dietz, W. H. (2004). Overweight in childhood and adolescence. New England Journal of Medicine, 350(9), 855857.

Dobbins, D., McCready, M., \& Rackas, L. (2016). Unequal access: Barriers to early childhood education for boys of color. Princeton, NJ: Robert Wood Johnson Foundation. 
Duyff, R. L. (2012). American dietetic association complete food and nutrition guide. Houghton Mifflin Harcourt.

Erol, F. Z. (2017). Çoklu zekâ kuramına dayalı beslenme eğitiminin okul öncesi eğitim kurumuna devam eden 60-72 ay grubundaki çocukların beslenme alı̧kanlıklarına etkisinin incelenmesi (Yayınlanmamış yüksek lisans tezi). Necmettin Erbakan Üniversitesi, Konya.

Flick, U. (2018). Designing qualitative research. Sage Publications.

Gao, S., Wei, Y., Bai, J., Lin, C. \& Li, H. (2009). Young children's affective decision-making in a gambling task: Does difficulty in learning the gain/loss schedule matter?. Cognitive Development, 24(2), 183-191.

Garon, N., \& Moore, C. (2004). Complex decision-making in early childhood. Brain and Cognition, 55(1), 158170.

Goloğlu, S. (2009). Fen eğitiminde sosyo-bilimsel aktivitelerle karar verme becerilerinin geliştirilmesi: Dengeli beslenme (Yayınlanmamış yüksek lisans tezi). Marmara Üniversitesi, İstanbul.

Gökçay, G., \& Garipağaoğlu, M. (2002). Çocukluk ve ergenlik döneminde beslenme. Saga yayınları.

Guba, E. G., \& Lincoln, Y. S. (1982). Epistemological and methodological bases of naturalistic inquiry. ECTJ, 30(4), 233-252.

Hancock, D. R., \& Algozzine, B. (2006). Doing case study research: A practical guide for beginners researchers. New York: Teachers College.

Herman, B. C., Zeidler, D. L., \& Newton, M. (2018). Students' emotive reasoning through place-based environmental socioscientific issues. Research in Science Education, 50, 2081-2109.

Houser, J. (2015). Nursing research: reading, using, and creating evidence. Burlington: Jones ve Bartlett Learning.

Hu, C., Ye, D., Li, Y., Huang, Y., Li, L., Gao, Y., \& Wang, S. (2010). Evaluation of a kindergarten-based nutrition education intervention for pre-school children in China. Public Health Nutrition, 13(2), 253-260.

Işkın, M., \& Sarışık, M. (2017). Öğrencilerin besin tüketim alışkanlıkları üzerine bir araştırma. Türk Turizm Araştırmaları Dergisi, 1(1), 33-42.

Jaime, P. C., \& Lock, K. (2009). Do school based food and nutrition policies improve diet and reduce obesity?. Preventive Medicine, 48(1), 45-53.

Jung, T., Huang, J., Eagan, L., \& Oldenburg, D. (2019). Influence of school-based nutrition education program on healthy eating literacy and healthy food choice among primary school children. International Journal of Health Promotion and Education, 57(2), 67-81.

Karamanlı, E. (2019). Sosyobilimsel konularda sımı içi destekli blog uygulamalar ile ortaokul öğrencilerinin argümantasyon düzeylerinin ve informal akıl yürütme örüntülerinin incelenmesi (Yayınlanmamış yüksek lisans tezi). Mersin Üniversitesi, Mersin.

Kasnakoğlu, H. ,\& Ülgüray, D. (2003). Ulusal Gıda ve Beslenme Stratejisi Çalışma Grubu Raporu. İktisadi Sektör ve Koordinasyon Genel Müdürlüğ̈̈, Devlet Planlama Teşkilatı, (2670).

Kikafunda, J. K., \& Tumwine, J. K. (2006). Diet and socio-economic factors and their association with the nutritional status of pre-school children in a low income suburb of Kampala City, Uganda. East African medical journal, 83(10), 565-574.

Klosterman, M. L., \& Sadler, T. D. (2010). Multi-level assessment of scientific content knowledge gains associated with socioscientific issues-based instruction. International Journal of Science Education, 32(8), 1017-1043.

Kobak C. (2009) Okul öncesi dönemde (3-6 yaş) ana çocuk sağlığı ve anaokulundaki çocukların beslenme özelliklerinin karşılaştırılması (Yayınlanmamış yüksek lisans tezi). İstanbul Üniversitesi, İstanbul 
Koç, M. (2020). Okul öncesi çocuklara verilen beslenme eğitimi sonrasında çocukların beslenme bilgi ve davranışları üzerine etkisinin değerlendirilmesi (Yayınlanmamış yüksek lisans tezi). Aydın Adnan Menderes Üniversitesi, Aydin.

Koçyiğit, A. (2015). Fen bilimleri öğretmenlerinin genetiği değiştirilmiş organizmalar (GDO) ve ürünleri konusunda bilgi düzeyleri, öz yeterlik inançları, tutum ve risk algılarının belirlenmesi (Yayınlanmamış yüksek lisans tezi). Ondokuz Mayıs Üniversitesi, Samsun.

Kutluay-Merdol, T. (2012). Küreselleşmenin beslenme biçimine etkilerinin tarihsel gelişim bakış açısı ile değerlendirilmesi. T. Kutluay-Merdol (Ed.), Beslenme antroplojisi içinde (s. 17-33). Ankara: Hatipoğlu Basım ve Yayım.

Kutluca, A. Y. (2021). An investigation of elementary teachers' pedagogical content knowledge for socioscientific argumentation: The effect of a learning and teaching experience. Science Education. 105(4), 743-775.

Kutluca, A. Y., \& Aydın, A. (2017). Changes in pre-service science teachers' understandings after being involved in explicit nature of science and socioscientific argumentation processes. Science $\mathcal{E}$ Education, 26(6), 637-668.

Lanuza, F., Morales, G., Hidalgo-Rasmussen, C., Balboa-Castillo, T., Ortiz, M. S., Belmar, C., \& Muñoz, S. (2020). Association between eating habits and quality of life among Chilean university students. Journal of American College Health, 1-7.

Lee, Y. C. (2007). Developing decision-making skills for socio-scientific issues. Journal of Biological Education, 41(4), 170-177.

Li, F., Yuan, Y., Xu, X., Chen, J., Li, J., He, G., \& Chen, B. (2020). Nutrition education practices of health teachers from shanghai k-12 schools: The current status, barriers and willingness to teach. International journal of Environmental Research and Public Health, 17(1), 86-95.

Mata, F., Sallum, I., Moraes, P. H. P. D., Miranda, D. M., \& Malloy-Diniz, L. F. (2013). Development of a computerised version of the Children's Gambling Task for the evaluation of affective decision-making in Brazilian preschool children. Estudos de Psicologia (Natal), 18(1), 151-157.

Mennella, J. A., Nicklaus, S., Jagolino, A. L., \& Yourshaw, L. M. (2008). Variety is the spice of life: strategies for promoting fruit and vegetable acceptance during infancy. Physiology \& Behavior, 94(1), 29-38.

Merriam, S. B. (2013). Nitel araştırma: Desen ve uygulama için bir rehber. Nobel Yayıncılık.

Miles, M. B., \& Huberman, A. M. (2016). Genişletilmiş bir kaynak kitap: Nitel veri analizi (S. Akbaba-Altun ve A. Ersoy, Çev. Ed.) Ankara: Pegem Akademi.

Murray, D. J., Boyle, W. A., Beyatte, M. B., Knittel, J. G., Kerby, P. W., Woodhouse, J., \& Boulet, J. R. (2018). Decision-making skills improve with critical care training: Using simulation to measure progress. Journal of Critical Care, 47, 133-138.

Neelon, S. E. B., \& Briley, M. E. (2011). Position of the American Dietetic Association: benchmarks for nutrition in child care. Journal of the American Dietetic Association, 111(4), 607-615.

Obalı, H. (2009). Okulöncesi eğitimi almakta olan altı yaş grubu çocuklarına verilen proje yaklaşımıyla beslenme eğitiminin beslenme bilgi düzeyine etkisi (Yayınlanmamış doktora tezi). Selçuk Üniversitesi, Konya.

Onbaşı, Z. Ç. (2017). Adölesan voleybol oyuncularınn beslenme bilgi düzeyleri, beslenme durumları ile sıvı tüketimlerine beslenme eğitiminin etkisi (Yayınlanmamış yüksek lisans tezi). Başkent Üniversitesi, Ankara.

Osborne, J. (2014). Teaching scientific practices: Meeting the challenge of change. Journal of Science Teacher Education, 25(2), 177-196. 
Ozden, M. (2020). Elementary school students' informal reasoning and its' quality regarding socio-scientific 1ssues. Eurasian Journal of Educational Research, 20(86), 61-84.

Ozturk, N., \& Yilmaz-Tuzun, O. (2017). Preservice science teachers' epistemological beliefs and informal reasoning regarding socioscientific issues. Research in Science Education, 47(6), 1275-1304.

Panunzio, M.F., Antoniciello, A., Pisano, A., \& Dalton, S. (2007). Nutrition education intervention by teachers may promote fruit and vegetable consumption in Italian students. Nutrition Research, 27(9), 524-528.

Pekdoğan, S. (2015). Karar verme becerileri eğitim programının 5-6 Yaş çocuklarının karar verme becerileri üzerindeki etkisinin incelenmesi (Yayınlanmamış doktora tezi). Gazi Üniversitesi, Ankara.

Pekdoğan, S., \& Ulutaş, İ. (2018). Karar verme becerileri eğitim programının okul öncesi dönem çocuklarının karar verme becerileri üzerindeki etkisi. İnönü Üniversitesi Ĕ̆itim Fakültesi Dergisi, 19(1), 230-244.

Pratiwi, S., Prahani, B. K., Suryanti, S., \& Jatmiko, B. (2019). The effectiveness of PO2E2W learning model on natural science learning to improve problem solving skills of primary school students. Journal of Physics: Conference Series: IOP Publishing.

Ransley, J. K., Taylor, E. F., Radwan, Y., Kitchen, M. S., Greenwood, D. C., \& Cade, J. E. (2010). Does nutrition education in primary schools make a difference to children's fruit and vegetable consumption?. Public Health Nutrition, 13(11), 1898-1904.

Ruel, M. T., \& Alderman, H. (2013). Nutrition-sensitive interventions and programmes: how can they help to accelerate progress in improving maternal and child nutrition?. The Lancet, 382(9891), 536-551.

Sabbağ, Ç. (2011). İlköğretim öğrencilerine verilen beslenme eğitiminin beslenme tutum ve davranışlarına etkisinin değerlendirilmesi. Grda Teknolojileri Elektronik Dergisi, 6(3), 1-13.

Sadler, T. D. (2004). Informal reasoning regarding socioscientific issues: A critical review of research. Journal of Research in Science Teaching, 41(5), 513-536.

Sadler, T. D., \& Fowler, S. R. (2006). A threshold model of content knowledge transfer for socioscientific argumentation. Science Education, 90(6), 986-1004.

Sadler, T. D., \& Zeidler, D. L. (2005). The significance of content knowledge for informal reasoning regarding socioscientific issues: Applying genetics knowledge to genetic engineering issues. Science Education, 89(1), 71-93.

Savage, J. S., Peterson, J., Marini, M., Bordi Jr, P. L., \& Birch, L. L. (2013). The addition of a plain or herbflavored reduced-fat dip is associated with improved preschoolers' intake of vegetables. Journal of the Academy of Nutrition and Dietetics, 113(8), 1090-1095.

Schwartz, D., Dodge, K. A., Pettit, G. S., \& Bates, J. E. (2000). Friendship as a moderating factor in the pathway between early harsh home environment and later victimization in the peer group. Developmental Psychology, 36(5), 646-662.

Sharma, S. V., Hedberg, A. M., Skala, K. A., Chuang, R. J., \& Lewis, T. (2015). Feasibility and acceptability of a gardening-based nutrition education program in preschoolers from low-income, minority populations. Journal of Early Childhood Research, 13(1), 93-110.

Sicimoğlu, B. (2020). 7. sınıf öğrencilerinin bilimsel okuryazarlık düzeylerinin sosyobilimsel konu temelli informal akıl yürütme düzeylerine göre incelenmesi: Bir karma yöntem araştırması. Marmara Üniversitesi Atatürk Ĕ̆itim Fakültesi Eğitim Bilimleri Dergisi, 52(52), 137-158.

Slaughter, V., \& Ting, C. (2010). Development of ideas about food and nutrition from preschool to university. Appetite, 55(3), 556-564. 
Şen, B. (2020). 1-5 yaş çocukların beslenme durumlarının antropometrik ölçümler ve ailelerin beslenme bilgisi sağllk okuryazarlı̆̆ı durumları ile değerlendirilmesi (Yayınlanmamış yüksek lisans tezi). İstanbul Üniversitesi, İstanbul.

Tallon, J. M., Dias, R. S., Costa, A. M., Narciso, J., Barros, A., \& Silva, A. J. (2020). Pilot evaluation of an interactive multimedia platform to provide nutrition education to Portuguese adolescents. European Journal of Public Health, 30(2), 353-357.

Tatlow-Golden, M., Hennessy, E., Dean, M., \& Hollywood, L. (2013). ‘Big, strong and healthy'. Young children's identification of food and drink that contribute to healthy growth. Appetite, 71, 163-170.

Uzşen, H. (2016). Okul çağı çocuklarının beslenme alışkanlıklarının değerlendirilmesi ve oyunla beslenme eğitiminin beslenme alı̧̧kanlıklarına etkisi. (Yayınlanmamış yüksek lisans tezi). Ege Üniversitesi, İzmir.

Venville, G. J., \& Dawson, V. M. (2010). The impact of a classroom intervention on grade 10 students' argumentation skills, informal reasoning, and conceptual understanding of science. Journal of Research in Science Teaching, 47(8), 952-977.

Wyse, R., Campbell, E., Nathan, N., \& Wolfenden, L. (2011). Associations between characteristics of the home food environment and fruit and vegetable intake in preschool children: a cross-sectional study. BMC public health, 11(1), 1-10.

Yang, F. Y., \& Anderson, O. R. (2003). Senior high school students' preference and reasoning modes about nuclear energy use. International Journal of Science Education, 25(2), 221-244.

Yıldırım, A., \& Şimşek, H. (2013). Sosyal bilimlerde nitel araştırma yöntemleri. Seçkin Yayıncılık.

Yin, R. K. (2011). Applications of case study research. Sage Publications.

Zarnowiecki, D., Dollman, J., \& Sinn, N. (2011). A tool for assessing healthy food knowledge in 5-6-year-old Australian children. Public Health Nutrition, 14(7), 1177-1183.

Zeidler, D. L., \& Nichols, B. H. (2009). Socioscientific issues: Theory and practice. Journal of Elementary Science Education, 21(2), 49-58.

Zeidler, D. L., Herman, B. C., \& Sadler, T. D. (2019). New directions in socioscientific issues research. Disciplinary and Interdisciplinary Science Education Research, 1(1), 1-9.

Zembat, R., \& Unutkan, P. Ö. (2005). Problem çözme becerilerinin gelişimi: Gelişim ve eğitimde yeni yaklaşımlar. Morpa Yayınları, İstanbul. 


\section{EXTENDED ABSTRACT}

\section{Introduction}

In general, the aim of all societies is to ensure that children are healthy and independent individuals in all aspects. Many factors are effective in achieving this. One of them is nutrition. Individuals become mentally, physically, socially, emotionally developed, productive and healthy when they have a balanced and adequate diet (Oball, 2009). Scientists agree that adequate and balanced nutrition is necessary for the development of children's cognitive and behavioural skills and to increase their learning capacity (Ruel \& Alderman, 2013). However, nutrition education has not become widespread because the importance of nutrition is not well understood. Nutrition programs to be given at school in order to establish the awareness of balanced and healthy nutrition in early childhood play an important role in both the physical and healthy development of children and in increasing their school success. In addition, it is thought that qualified nutrition education in early childhood will improve children's nutritional behaviours, decisions and reasoning qualities (Slaughter \& Ting, 2010). Most of the studies in the literature on this context have shown that there is a significant relationship between obesity and the relationship with parents and siblings (Black \& Heidkamp, 2018; Sabbağ, 2011). It has been suggested that the intervention to be done for this should be done in the school and home environment. Therefore, including children in quality nutrition education in this period will enable them to make their decisions through qualified reasoning patterns (Hu et al. 2010). In the based on this rational, the existing literature has been examined in depth and it has been seen that separate studies have been conducted on socioscientific issues, decision making and nutrition education (Çapkınoğlu, 2015; Herman, Zeidler, \& Newton, 2018; Ransley et al., 2010). However, there are no studies in which nutrition, decision-making and reasoning patterns are evaluated together at the preschool education level. In summary, on the basis of the rationales mentioned above and the gap in the literature, the purpose of this research is to explore how nutrition education affects children's nutritional decisions and reasoning patterns.

\section{Method}

The study was conducted with case study, which is one of the qualitative research methods (Hancock \& Algozzine, 2006). Situations covered in this study are children's dietary decisions and reasoning patterns. Therefore, the research has a multiple case study design (Yin, 2011). Eight children aged 60-72 months studying in a preparatory class in a private kindergarten in Elazığ in the 2019-2020 academic year participated in the research. Children were included in nutrition education for a total of six weeks, two days a week. Nutrition education was carried out with the help of 12 activities, two days a week, in six weeks. Although it is at the forefront to monitor nutrition education and decision-making factors in the prepared activities, it is also aimed to improve the cognitive, psychomotor, creativity, social emotional, language and music skills of children in early childhood. The main data source in this study is sample menu options. Sample menus were prepared together with the nutritionist. Afterwards, another expert nutritionist was consulted to increase internal validity. As a result, the menus took their final form as three separate meals of breakfast, lunch, and dinner, and in three different ways, healthy, unhealthy, healthy-looking and unhealthy. At the beginning and end of the education, children were presented with breakfast, lunch and dinner menus prepared by a nutritionist in a way that would be healthy, seemingly healthy and unhealthy. Children were asked to choose one of the three alternative menus. While the children's decisions were scored as $-1,0,1$ before and after the education, their reasoning patterns were evaluated through an analytical rubric.

\section{Results}

As a result of the analyzes carried out in this study, it was observed that children generally tend to have an unhealthy diet in the choices made before nutrition education. The reason for this situation is that the children have not received nutrition education before. In general, it has been in the direction of choosing the foods they like directly without considering the unhealthy decisions made by children before education. Another remarkable element in this study is that nutritional decisions are made individually and in groups before the training. While no training was given in terms of nutrition yet, it was observed that some of the participants could make different decisions even though the same menus were offered in the same week. 
On the other hand, it was determined that the reasoning patterns used by the participants while making decisions before the nutrition education were mostly in the emotional direction. Participants who used the emotional reasoning pattern to a large extent used the intuitive reasoning pattern in the second place. Since it is known that students do not have any prior knowledge in terms of nutrition education, it is an expected result that rational decisions are less. After the nutrition education, it was determined that the majority of the participants used the rational reasoning pattern, while they used the rational emotional reasoning pattern in the second place. The fact that students use rational reasoning patterns after the training shows that the education is efficient and that students can approach more rationally when they have knowledge about a subject.

\section{Conclusion}

The results reached after the in-depth analysis carried out to explore the children's decisions before and after nutrition education and the reasoning patterns they use while making these decisions are as follows:

- Children who tended to eat unhealthy before the nutrition education tended to eat healthy after the nutrition education.

- Nutrition education has led children to make more rational decisions in menu selection.

- Before nutrition education, children tend to make more emotional decisions.

- After the nutrition education, the children made more rational reasoning.

These results were discussed in depth based on the literature and pedagogical recommendations were made. 